\title{
An Unappreciated Constraint on the President's Pardon Power
}

Aaron Rappaport

Follow this and additional works at: https://opencommons.uconn.edu/law_review

\section{Recommended Citation}

Rappaport, Aaron, "An Unappreciated Constraint on the President's Pardon Power" (2020). Connecticut Law Review. 444.

https://opencommons.uconn.edu/law_review/444 


\section{CONNECTICUT LAW REVIEW}

\begin{tabular}{c}
\hline \hline VOLUME 52 \\
\hline \hline Arril 2020 \\
An Unappreciated Constraint on the President's \\
Pardon Power
\end{tabular}

\section{AARON RAPPAPORT}

Most commentators assume that, except for the few restrictions expressly mentioned in the U.S. Constitution, the President's pardon power is unlimited. This Paper suggests that this common view is mistaken in at least one unexpected way. Presidential pardons must satisfy a modest procedural rule: they must list the specific crimes covered by the pardon. The "specificity requirement" means that vague and broadly worded pardons are invalid.

This claim bears a significant burden of persuasion, since it runs so counter to accepted opinion. Nonetheless, that burden can be met. This Paper's argument rests on an originalist understanding of the constitutional text, an approach that the Supreme Court has repeatedly endorsed as the appropriate method for interpreting the Pardon Clause. That approach leaves little doubt that a specificity requirement is a binding limitation on the President's pardon power.

The final part of this Paper examines the ramifications of the specificity requirement for federal criminal investigations, particularly investigations into Russia's interference in the 2016 presidential election. The specificity requirement may prove surprisingly significant in this latter context, since it both raises the political costs, and narrows the legal scope, of any pardon the President might grant to former campaign advisors. In effect, the requirement strengthens the hand of investigators, increasing the likelihood that defendants will cooperate with the prosecution. In so doing, the specificity requirement serves as an unexpected ally in the fight for political accountability and in defense of the rule of law. 


\section{ARTiCle CONTENTS}

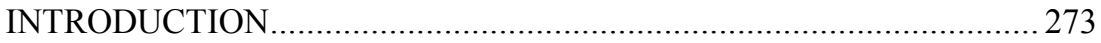

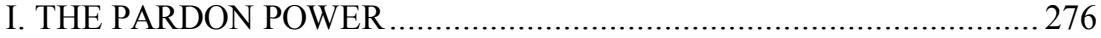

II. PARDONS AND THE COMMON LAW ……….................................... 280

A. Pardons Before the Glorious ReVOLUtion ........................... 281

B. LORD DANBY AND L'AFFAIRE FRANCAISE …............................... 284

C. Royal Prerogatives After the Glorious Revolution .......... 287

D. The SPECIFICITY ReQUiREMENT AND THE COMMON LAW ...............28

E. The COMMON LAW AND THE CONSTITUTION.................................293

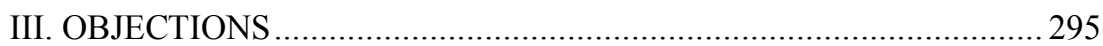

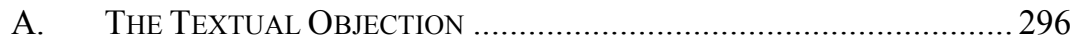

B. The ObJeCtion from Historical Practice ................................ 300

IV. DONALD TRUMP AND THE SPECIFICITY REQUIREMENT.........312

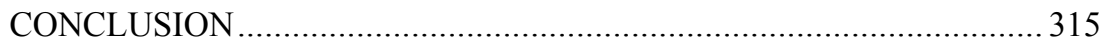

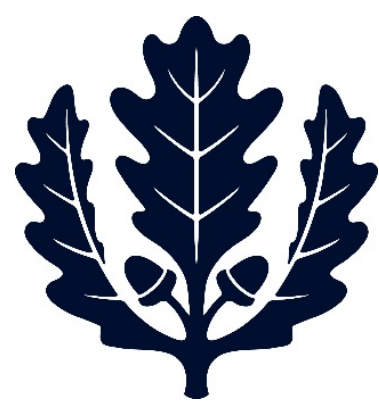




\title{
An Unappreciated Constraint on the President's Pardon Power
}

\author{
AARON RAPPAPORT *
}

\section{INTRODUCTION}

Not since President Ford pardoned Richard Nixon has the pardon power been the focus of so much media and public attention. As Donald Trump's legal troubles have multiplied, speculation has intensified that the President may attempt to use the power to insulate associates and advisors from criminal liability. ${ }^{1}$ A pardon, it is believed, would eliminate the risk of federal prosecution, undermining the leverage prosecutors have to persuade these men to offer possibly incriminating information about the President.

To be sure, a federal pardon would not eliminate all pressure on Trump's associates. Federal pardons, after all, insulate individuals only from federal prosecutions, not state charges. The New York State Attorney General, among others, has been looking into allegations of wrongdoing by some of Trump's associates. ${ }^{2}$ Nonetheless, eliminating federal exposure would mitigate the potential threats against these individuals and, depending on the specific facts of the cases, might eliminate criminal liability entirely. In this sense, a federal pardon could pose a significant roadblock to prosecutors

* Professor of Law, University of California, Hastings College of the Law. Thanks to Mark Osler, Ian Williams, and Zachary Price for comments on an earlier version of this Article. Special thanks to Erin Barlow, Jennifer Bentley, Deborah Brundy, Ally Girouard, Sarah Glendon, Brenly Pereira, and Andrew Johnson for exceptional research assistance.

${ }^{1}$ Even more controversially, the President might attempt to pardon himself. That possibility raises distinct legal issues that have been addressed in other papers. See, e.g., Brian C. Kalt, Pardon Me?: The Constitutional Case Against Self-Pardons, 106 YALE L.J. 779, 781 (1996) (discussing the constitutionality of a presidential self-pardon through a historical, textual, structural, and doctrinal analysis); Robert Nida \& Rebecca L. Spiro, The President as His Own Judge and Jury: A Legal Analysis of the Presidential Self-Pardon Power, 52 OKLA. L. REV. 197, 222 (1999) (analyzing the self-pardon from various perspectives to conclude that the self-pardon is constitutional); Mark Strasser, The Limits of the Clemency Power on Pardons, Retributivists, and the United States Constitution, 41 BRANDEIS L.J. $85,149-52$ (2002) (discussing the presidential self-pardon). As such, the lawfulness of self-pardons is not directly addressed below.

${ }^{2}$ See, e.g., Natasha Bertrand, New York Prosecutors May Pose a Bigger Threat to Trump than Mueller, ATLANTIC (Aug. 24, 2018), https://www.theatlantic.com/politics/archive/2018/08/new-yorkprosecutors-allen-weisselberg-trump/568516/; David A. Fahrenthold, New York Attorney General Moves to Open a State Criminal Tax Investigation into Michael Cohen, WASH. Post (Aug. 23, 2018), https://www.washingtonpost.com/politics/new-york-attorney-general-moves-to-open-a-state-criminaltax-investigation-into-michael-cohen/2018/08/23/a320754e-a 746-11e8-8fac12e98c13528d_story.html?noredirect $=$ on\&utm_term $=$.ddfade1542f5. 
hoping to unravel what precisely happened during the presidential election of 2016.

If Trump pardons one or more of these individuals, could an argument be made that these pardons are invalid? The common view is "no." The general assumption is that the President's pardon power is virtually unlimited. The President might suffer political fallout from granting immunity, but the pardons themselves are widely seen as beyond judicial review. That is true even if those pardons are issued for corrupt or self-interested reasons. ${ }^{3}$

This Paper suggests that this common view is mistaken in at least one unexpected way. Though the substantive scope of the pardon power is broad, one modest procedural rule must be followed: the pardon must identify the specific crimes covered by the order. ${ }^{4}$ The "specificity requirement," as I will call it, means that vague and broadly worded pardons are not valid. ${ }^{5}$

The claim that a specificity requirement exists may sound doubtful, since it runs against the widespread view that the President's pardon power is unfettered. It also seems to run against historical practice. President Ford's pardon of Nixon was but the most famous example of a vague and general pardon that brought a federal prosecution to a halt. ${ }^{6}$ According to its terms, Nixon's pardon applied to "all offenses against the United States" during his administration; the wrongdoings were never specified. ${ }^{7}$ Even beyond this famous (or, depending on one's viewpoint, infamous) example, the existence of a specificity requirement has never been acknowledged by the Supreme Court. ${ }^{8}$

\footnotetext{
${ }^{3}$ Several commentators have suggested that a pardon issued for corrupt reasons could result in a separate charge against the President for obstruction of justice. See, e.g., Meghan Keneally, Yes, Trump Can Pardon Manafort and Cohen, But It Would Be a 'Legal and Strategic Error,' Expert Says, ABC NEws (Aug. 23, 2018, 7:23 PM), https://abcnews.go.com/Politics/trump-pardon-manafort-cohen-legalstrategic-error-expert/story?id=57355504; James D. Robenalt, The Pardon Power Can Be Used to Obstruct Justice. Just Ask Richard Nixon, Hist. News NeTwork (Apr. 4, 2018), https:/historynewsnetwork.org/article/168686. For a somewhat more skeptical view, see Daniel J. Hemel \& Eric A. Posner, Presidential Obstruction of Justice, 106 CALIF. L. REV. 1277, 1281-82 (2018). However, even if separate obstruction charges could be brought, the pardons themselves would likely be upheld and remain binding.

${ }^{4}$ This is a procedural constraint in the sense that it imposes restrictions on how pardons are structured, rather than on who or what can be pardoned.

${ }^{5}$ This is not the first paper to mention a specificity requirement. In a piece published after the Watergate controversy, Hugh Macgill explores the possibility of such a requirement. See Hugh C. Macgill, The Nixon Pardon: Limits on the Benign Prerogative, 7 ConN. L. Rev. 56, 74-84 (1974) (discussing several possible constraints on the President's pardon power, including the specificity requirement). This Article builds and expands upon that work.

${ }^{6}$ The significance of this pardon is discussed in more depth later in this Paper. See infra Part III.B.

${ }^{7}$ Proclamation No. 4311, 39 Fed. Reg. 32,601, 32,601-02 (Sept. 10, 1974).

${ }^{8}$ Petitioners before the Supreme Court have raised the specificity argument at least once. In Burdick v. United States, the petitioner argued that, "the pardon is illegal for the absence of specification, not reciting the offenses upon which it is intended to operate; worthless, therefore, as immunity." 236 U.S. 79, 93 (1915). The Court, however, declined to rule on the issue, preferring instead to deny the
} 
Given this background, the claim that a specificity requirement exists faces a heavy burden of persuasion. Nonetheless, the burden can be met. This Paper demonstrates that the arguments in favor of a specificity requirement are not only plausible, but highly persuasive. The argument rests on an originalist reading of the pardon power, an approach that the Supreme Court has repeatedly endorsed for interpreting the Pardon Clause. The Court has explained that original intent can be discerned by looking at English practices before the Constitution's drafting. The common law, in short, informed the Framers' understanding of the President's pardon power.

Perhaps surprisingly, relatively little effort has been made to explore the dimensions of the pardon power in England during the first half of the eighteenth century. ${ }^{9}$ A closer look reveals that a specificity requirement was widely understood to exist in English law during the period. In this regard, the originalist methodology favored by the Supreme Court confirms that a specificity requirement should be part of our own understanding of the pardon power in the U.S. Constitution.

Even if a specificity requirement exists, one might wonder whether it would matter as a check on presidential misuse of the pardon. A specificity requirement, after all, is a rather modest restriction; it does not prevent a President from issuing a pardon to whomever he wishes on whatever grounds. Consequently, it would not prevent the President from pardoning any of his associates, for any crime committed, for any reason.

Yet, a specificity requirement might prove unexpectantly significant, especially in cases where the President's associates have been accused of crimes that, if specified in a pardon document, would prove highly embarrassing to the President himself. It is one thing for a President to offer a general, non-specific pardon that covers "all crimes committed" by an associate. It is quite another to list a series of offenses, such as money laundering, wire fraud, and (in the worst case) conspiracy to interfere with the electoral process. It is widely understood that the receipt of a pardon represents an acceptance of guilt. ${ }^{10}$ Consequently, the specific articulation of crimes pardoned offers the public a clear idea of what precisely the offender is guilty of, while a vague pardon allows the President to avoid

petitioner's claim on other grounds. Id. at 93-95.

${ }^{9}$ There are a few exceptions. See, e.g., William F. Duker, The President's Power to Pardon: A Constitutional History, 18 WM. \& MARY L. REV. 475, 499-500 (1977) (examining English pardon power in the first half of the eighteenth century); Stanley Grupp, Some Historical Aspects of the Pardon in England, 7 AM. J. LEGAL HIST. 51, 51-62 (1963) (same).

${ }^{10}$ See Burdick, 236 U.S. at 94 (noting that a pardon requires an individual "to confess his guilt in order to avoid a conviction of it"); see also Pardoning Power, 11 Op. Att'y Gen. 227, 228 (1865) ("There can be no pardon where there is no actual or imputed guilt."). For a different and nuanced view, see Eugene Volokh, Opinion, Is Accepting a Pardon an Admission of Guilt?, WASH. POST (Aug. 26, 2017), https://www.washingtonpost.com/news/volokh-conspiracy/wp/2017/08/26/is-accepting-a-pardon-anadmission-of-guilt/?utm_term=.6b626b5480c2. 
responsibility by hiding behind the ambiguity of the pardon's general language. In this regard, a specificity requirement raises the political costs of making a pardon.

The power of the specificity requirement is not surprising. It is premised on the idea that transparency is the best disinfectant when it comes to governmental abuse. Requiring clarity about what is being pardoned can help deter the most egregious uses of the pardon-those employed for partisan or corrupt reasons. It can also promote political accountability-and in extreme cases trigger impeachment proceedings - should the power of the pardon be misused. In short, it helps ensure that the "benign prerogative" of the pardon remains truly benign. ${ }^{11}$

This Paper proceeds in four parts. Part I highlights the importance of using an originalist methodology when interpreting the Pardon Clause of the Constitution and how that approach requires a careful exhumation of common law practices at the time of the Constitution's adoption. Part II examines these common law practices in detail. This Part demonstrates that a clear specificity requirement existed in the common law at the time of the Constitution's drafting. It also explains how the requirement is consistent with core constitutional values embraced by the Framers during the drafting period.

Part III evaluates two major counterarguments. One is a textual argument, grounded in the specific language of the Pardon Clause. The other is an argument based on historical practice, which is essentially an argument that the specificity requirement is invalid because it is inconsistent with the way pardons have been used in the past. Both objections, we will see, are superficially appealing but ultimately unpersuasive.

Part IV returns to the controversies surrounding President Trump and his inner circle of advisors and associates. This Part elaborates how the specificity requirement could generate problems for the President should he attempt to use the pardon power to short-circuit federal investigations into possible Administration corruption. The specificity requirement limits the effectiveness of any pardon that Trump issues, thus diminishing its value to any offender contemplating whether to cooperate with investigators. In doing so, the specificity requirement serves as an unexpected ally in the fight for political accountability and in defense of the rule of law.

\section{THE PARDON POWER}

It is widely recognized that the federal pardon power is expansive in its scope. The Constitution provides that: "The President ... shall have Power to grant Reprieves and Pardons for Offenses against the United States,

11 THE Federalist No. 74 (Alexander Hamilton) (referring to the "benign prerogative of pardoning"). 
except in Cases of Impeachment." ${ }^{\prime 2}$ As the Supreme Court has affirmed, the pardon power has few limitations. The President can issue a pardon at any time after a crime has been committed, even prior to arrest or indictment. ${ }^{13}$ The pardon can be granted for any crime without exception. ${ }^{14}$ The President need not articulate reasons for the pardon. Indeed, it is commonly thought that the motivation for the pardon is not reviewable by courts regardless of the appearance of unseemly or inappropriate motivations. ${ }^{15}$ Finally, the pardon power cannot be restricted by Congress through legislation. ${ }^{16}$

Of course, the pardon power is not entirely unfettered. The text of the Constitution spells out two clear constraints. First, the power conferred by the Constitution is restricted to federal crimes ("offenses against the United States"). ${ }^{17}$ Second, a pardon cannot insulate an official from the effects of an impeachment proceeding. ${ }^{18}$ Apart from these textual constraints, however, many doubt whether any other limit exists. In dicta, the Supreme Court itself has stated that, beyond these two exceptions, "[t]he power thus conferred is unlimited." $" 19$

Yet the Court's own decisions recognize that the reality is more complicated. In various rulings, the Supreme Court has endorsed modest non-textual limits on the validity of pardons. These might be called "implicit" limitations on the pardon power. In Burdick v. United States, for example, the Court stated that a pardon is valid only if accepted by the defendant. ${ }^{20}$ Thus, "acceptance" serves as a limitation on the pardon's

${ }^{12}$ U.S. CONST. art. II, § 2, cl. 1.

${ }^{13}$ Ex parte Grossman, 267 U.S. 87, 120 (1925) ("The executive can reprieve or pardon all offenses after their commission, either before trial, during trial or after trial."); Ex parte Garland, 71 U.S. (4 Wall.) 333, 380 (1867) ("The [pardon] power . . . may be exercised at any time after [the] commission [of a crime], either before legal proceedings are taken, or during their pendency, or after conviction and judgment. ... If granted before conviction, it prevents any of the penalties and disabilities consequent upon conviction from attaching; if granted after conviction, it removes the penalties and disabilities, and restores him to all his civil rights . . ."). This view also seems to be supported by debates at the constitutional convention - as William Duker writes, during the debates on the pardon power, "Luther Martin moved to insert 'after conviction' after the words 'reprieves and pardons,' but withdrew the motion after the persuasive argument of Mr. Wilson that a 'pardon before conviction might be necessary, in order to obtain the testimony of accomplices." Duker, supra note 9, at 501-02 (citation omitted).

${ }^{14}$ See Garland, 71 U.S. at 380 (The pardon power "extends to every offence known to the law.").

${ }^{15}$ See 20 Op. Att'y Gen. 330, 332 (1892) ("A pardon is a gracious act of mercy resting on any ground which the Executive may regard as sufficient to call for its exercise."); 20 RULING CASE LAW 518, 533 (William M. McKinney \& Burdett A. Rich eds., 1918) [hereinafter Ruling CASE LAW] ("Whatever may have been the reasons for granting the pardon, the courts cannot decline to give it effect, if it be valid upon its face.").

${ }^{16}$ Garland, 71 U.S. at 380 ("This power of the President is not subject to legislative control. . . . The benign prerogative of mercy reposed in him cannot be fettered by any legislative restrictions.").

${ }^{17}$ See supra note 12 and accompanying text.

${ }^{18} I d$.

${ }^{19}$ Garland, 71 U.S. at 380.

${ }^{20}$ See 236 U.S. 79, 89-91 (1915) (explaining that the convict must accept pardon for it to be effective). The circumstances under which an offender might reject a pardon are, as one might expect, 
validity. Similarly, the Supreme Court has ruled that a pardon must be pleaded to be valid. ${ }^{21}$ Failure to plead a pardon means that the court need not and should not take cognizance of it. In a separate case, the Supreme Court ruled that a President may pardon for criminal contempt but may not pardon a case involving civil contempt even if the sanction for that contempt is prison. ${ }^{22}$ Finally, the President cannot pardon a crime before it has been committed. $^{23}$

These examples illustrate that the Supreme Court has, in fact, recognized certain, modest, non-textual limitations on the pardon power. The question naturally arises: on what basis does the Court find these implicit limitations? The methodology employed by the Court is typically an originalist one: the Court has sought to identify the Framers' understandings regarding the scope of the pardon power at the time of the Constitution's adoption.

What sort of information informs that assessment? In the case of pardons, the sources are limited. The constitutional debates, for example, contain few references to the pardon power, and none are particularly substantive. ${ }^{24}$ The Federalist Papers provide little more insight, offering a

quite unusual. In Burdick, the defendant refused to testify against a co-conspirator on the grounds that his testimony might be self-incriminating. Id. at 86 . The President gave the defendant a pardon to nullify that argument, and thus to prevent him from "taking the Fifth." Id. To escape the snare, the defendant refused to accept the pardon. Id. The Supreme Court ruled that, by refusing the pardon, the defendant voided the grant, undermining the prosecution's strategy. Id. at 89-91.

In a subsequent case, the Supreme Court narrowed the scope of this rule, holding that the defendant's consent was not necessary when the President seeks to reduce a capital sentence to life in prison. Biddle v. Perovich, 274 U.S. 480 (1927). In a four-page opinion, the Court noted that the "opposite answer would ... deprive [the President] of the power in the most important cases and require him to permit an execution which he had decided ought not to take place." Id. at 487. The Court thus concluded: "We are of opinion that the reasoning of Burdick v. United States, is not to be extended to the present case." Id. at 487-88 (internal citation omitted).

${ }^{21}$ United States v. Wilson, 32 U.S. (7 Pet.) 150, 162 (1833).

${ }^{22}$ Ex parte Grossman, 267 U.S. 87, 111 (1925).

${ }^{23} \mathrm{See}$ id. at 120 (affirming in dicta that pardons will apply after commission of offense); Garland, 71 U.S. at 380 (same). The Department of Justice has long adopted this position, as well. See, e.g., 6 Op. Att'y Gen. 393, 403 (1854) ("[I]f a pardon could be granted in advance for offences to be committed thereafter, it would include a power to grant indulgences to commit crimes and offences, to license vice, to dispense with the sanction of the laws, without good motive, without reason, but solely by arbitrary will. .. A pardon for an offence not yet committed would be void.").

This may seem self-evident, but it certainly is not the only possible approach. In early English history, the King of England claimed the right to grant "dispensations," which were essentially a license to violate the law. See 6 William Searle Holdsworth, A History of ENGLish LaW 218 ("That in the Middle Ages a suspending and dispensing power was vested in the king is unquestionable."); Zachary S. Price, Enforcement Discretion and Executive Duty, 67 VAND. L. REV. 671, 690 n.63 (2014) (describing kings' access to dispensing power). The use of the power by James II was widely condemned, and the practice was ultimately prohibited by the English Bill of Rights. An Act Declaring the Rights and Liberties of the Subject and Settling the Succession of the Crown (Bill of Rights) 1689, 1 W. \& M. c. 2, 7 (Eng.).

${ }^{24}$ Schick v. Reed, 419 U.S. 256, 262 (1974) ("The records of the Constitutional Convention, as noted earlier, reveal little discussion or debate on $\S 2$, cl. 1, of Art. II."). 
single substantive discussion of the pardon power. ${ }^{25}$ Specifically, in Federalist 74, Hamilton defends the importance of giving the President alone the power to pardon. He concludes: "[T] he benign prerogative of pardoning should be as little as possible fettered or embarrassed." 26 That statement confirms that the power is broad, but at the same time it acknowledges that some constraints on that power may be necessary and appropriate.

Given the haziness of these sources, the Supreme Court has looked elsewhere for insight into the Founders' intent. Specifically, it has affirmed - repeatedly and consistently - that the key source for interpreting the scope of the pardon power should be English common law practices immediately before the drafting of the Constitution. ${ }^{27}$ Limitations on the pardon power that existed at common law should be incorporated into the constitutional scheme. As the Supreme Court explained in Ex parte Grossman:

The language of the Constitution cannot be interpreted safely except by reference to the common law and to British institutions as they were when the instrument was framed and adopted. The statesmen and lawyers of the Convention who submitted it to the ratification of the Conventions of the Thirteen States, were born and brought up in the atmosphere of the common law, and thought and spoke in its vocabulary. ... [W] hen they came to put their conclusions into the form of fundamental law in a compact draft, they expressed them in terms of the common law, confident that they could be shortly and easily understood. ${ }^{28}$

It was this deep familiarity with English law that explains why the Framers adopted the pardon authority with so little debate concerning its precise scope and meaning. ${ }^{29}$ In practice, the Supreme Court has relied upon

\footnotetext{
${ }^{25}$ THE FEDERALIST No. 74 (Alexander Hamilton).

${ }^{26} \mathrm{Id}$.

${ }^{27}$ See, e.g., Schick, 419 U.S. at 261-62 ("[T] $]$ he draftsmen were well acquainted with the English Crown authority to alter and reduce punishments as it existed in 1787."); Ex parte Wells, 59 U.S. (18 How.) 307, 311 (1855) ("At the time of the adoption of the constitution, American statesmen were conversant with the laws of England, and familiar with the prerogatives exercised by the crown. ... At that time both Englishmen and Americans attached the same meaning to the word pardon.... We must then give the word the same meaning as prevailed here and in England at the time it found a place in the constitution."); United States v. Wilson, 32 U.S. (7 Pet.) 150, 160 (1833) ("As this power had been exercised from time immemorial by the executive of that nation whose language is our language, and to whose judicial institutions ours bear a close resemblance; we adopt their principles respecting the operation and effect of a pardon, and look into their books for the rules prescribing the manner in which it is to be used by the person who would avail himself of it.").

${ }^{28}$ Grossman, 267 U.S. at 108-09.

${ }^{29}$ Schick, 419 U.S. at 260 (Because of their familiarity with the common law, the Framers did not "devote extended debate to [the Pardon Clause's] meaning.").
} 
these common law practices to identify many of the non-textual constraints on the pardon power, including cases holding that a pardon is valid only if accepted and pleaded by the defendant. ${ }^{30}$ The same approach underlies the Court's ruling that pardons may be granted for criminal but not civil contempt. ${ }^{31}$ Finally, the Court has relied on common law practices to resolve certain questions about the pardon's operation, such as whether the President may issue "conditional" pardons. ${ }^{32}$

In short, the Supreme Court has made clear that certain implicit limitations on the pardon power exist, and that these are rooted in the common law practices in use at the time of the Founding. The question then follows: Do other common law limitations exist, limitations that have yet to be recognized by the Court? In particular, does the common law embrace a "specificity requirement"? The answer, as the next part explains, is yes.

\section{PARDONS AND THE COMMON LAW}

The English common law is sometimes discussed as if it has a static meaning. But of course, the content of the English common law evolved over time as English society changed. Between the Middle Ages and the eighteenth century, England transformed from a near-absolute monarchy to something much closer to a representative government. The contours of the pardon power, a central prerogative of the Crown, changed accordingly. As the U.S. Supreme Court observed relatively recently, "[t]he history of [the pardon] power, which was centuries old, reveals a gradual contraction to avoid its abuse and misuse. Changes were made as potential or actual abuses were perceived ...."33 The implication is that our attention should be focused more on the common law authorities of the eighteenth century, the period right before the Constitution's drafting, than on earlier ages.

At the same time, to fully appreciate the common law practices at the time of the American Revolution, it is useful to have a historical perspective. Such a perspective highlights how restrictions on the pardon power in the mid-eighteenth century built upon limitations established in earlier periods. For that reason, the first section below briefly examines the early history of

\footnotetext{
${ }^{30}$ Burdick v. United States, 236 U.S. 79, 89-90 (1915) (relying on common law practices to hold that a pardon is only effective if accepted); Wilson, 32 U.S. (7 Pet.) at 161-62 (same).

${ }^{31}$ Grossman, 267 U.S. at 111 (explaining that in distinguishing between pardons for civil and criminal contempt, the Court expressly relies on English practices at the time of the Constitution's adoption).

${ }^{32}$ Ex parte Wells, 59 U.S. (18 How.) 307, 310-14 (1855).

${ }^{33}$ Schick, 419 U.S. at 260-61. As John Yoo put it, "[t]he eighteenth-century British constitution was composed of a series of unwritten principles .... These principles, which defined the relationship between the government and its people, and between the Crown and Parliament, had undergone significant change during the seventeenth and eighteenth centuries. The meaning and significance of these constitutional developments would have been familiar to ratifiers of the American Constitution." JOHN YOO, THE POWERS OF WAR AND PEACE 31-32 (2005).
} 
the pardon power in England, a period during which the early seeds of the specificity requirement were laid. The second section looks at the events leading to the Glorious Revolution, a pivotal event in the transformation of English political society. The third section then examines the period after the English Revolution (and immediately before the American one), when broader limits on the King's pardon power were imposed. ${ }^{34}$

\section{A. Pardons Before the Glorious Revolution}

Evidence of the King's power to pardon can be found early in English history. During the Anglo-Saxon period, the King was seen as having the power to grant mercy, a power only strengthened with the Norman conquest in the eleventh century. ${ }^{35}$ The power was not unique to the King-the Church and other entities shared the power to pardon-but the King was seen as the primary holder of that power. ${ }^{36}$

The centrality of the King in English society gave the pardon power a certain logic. Since crimes were offenses against the King, the King could grant mercy to criminals at his discretion. Of course, this ancient prerogative was not without its downsides. As a tool of discretion, the pardon power could be - and often was - abused. Pardons were granted at the request of favored nobles or offered in return for compensation or loyalty. ${ }^{37}$ Parliament's concerns about these kinds of abuses triggered a number of efforts to restrict its operation, including several during the fourteenth century. Most were either ignored or repealed under pressure from the King. ${ }^{38}$

\footnotetext{
${ }^{34}$ The Glorious Revolution of 1688 is a convenient point of demarcation in this discussion. In the centuries prior to that event, the King tended to have the upper hand over Parliament; the pardon power was correspondingly broad in scope. In the decades afterwards, Parliament was resurgent, and the pardon power was subject to increasing attempts at curtailment. We are not alone in focusing on the post-1688 period. See Patrick Cowlishaw, The Conditional Presidential Pardon, 28 Stan. L. REV. 149, 159-60 (1975) (asserting that focus should be on the post-1688 era because separation of powers becomes more significant in that period in England). Whether the Glorious Revolution itself marked a dramatic change in the institutional structure of English society, or whether it was a small part of a broader trend, remains a point of dispute among historians. See Gary W. Cox, Was the Glorious Revolution a Constitutional Watershed?, 72 J. ECON. HIST. 567, 568 (2012) ("I argue that the Glorious Revolution should have affected a narrower range of transactions than North and Weingast envisioned; but that it nonetheless had fundamental effects."); Steven C.A. Pincus \& James A. Robinson, What Really Happened During the Glorious Revolution? 1 (Nat'1 Bureau of Econ. Research, Working Paper No. 729, 2011) ("This account of the decisive and innovative nature of the Glorious Revolution has long been disputed by specialists in both political and economic history.").

${ }^{35}$ See Grupp, supra note 9, at 54-55.

363 U.S. Dep'T of Justice, The AtTorney General's Survey of Release Procedures: Pardon 28 (1939) [hereinafter 3 Survey of Release Procedures]; Grupp, supra note 9, at 55 (discussing the range of institutions that possessed the power of the pardon).

${ }^{37} 3$ SuRVEy of Release PROCEDURES, supra note 36, at 30, 32 (discussing abuses).

${ }^{38}$ The first efforts occurred at the start of the century, in 1308 and 1309. Duker, supra note 9, at 479-80. These were largely ignored by the King. Id. at 482 . After eliminating his opponents at the Battle
} 
But not all. Perhaps the most notable attempt occurred in 1389, when Parliament enacted the first "specificity requirement" in English law. The Act of 1389 (which I will refer to as the "Pardon Act") states that no pardon "shall be allowed before any justice for murder, or for the death of a man slain by await, assault, or malice prepensed, treason, or rape . . unless the same . . . be specified in the same charter., ${ }^{39}$ In short, without a specific articulation of the listed crimes, the King's pardon would not be deemed valid. ${ }^{40}$

The Pardon Act is notable as a forerunner to a much broader particularity requirement adopted later. But it was an extremely limited restriction on the royal prerogative. As a preliminary matter, it applied only to the most serious crimes: treason, rape, and murder. Moreover, it did not bar the King from granting pardons for these crimes; it only required him to specify the offenses to be absolved (and, in the case at least of homicide, the manner in which the killing occurred). ${ }^{41}$

In fact, the Act was even more limited than this. Because the King was recognized as having the ultimate authority to suspend the law, the Pardon Act did not actually bar the King from issuing a non-specific (i.e., a

of Boroughbridge, the King summoned Parliament. He directed them in 1322 to enact the Statutes of York that, among other things, restored the King's unrestricted powers over the pardon. During the next sixty-five years, Parliament repeatedly enacted statutes to restrict the King's power, but with limited effect (in the years 1328, 1336, 1352, and, as discussed in the text, 1389).

${ }^{39}$ Other Statutes Made at Westminster 1389, 13 Rich. 2 c. 1 (Eng.).

${ }^{40}$ The existence of a narrow specificity requirement is confirmed by Edwardo Coke. See, e.g., Edwardo CoKe, The Third Part of the Institutes of the LaWs of ENGLAND 236 (London, M. Flescher, for W. Lee, \& D. Pakeman 2d ed. 1648) ("Before this Statute of 13 R. 2, by pardon of all felonies, treason was pardoned, and so was murder . . . At this day by the pardon of all felonies, the death of man is not pardoned. These be excellent laws for direction, and for the peace of the Realm."). Coke published his masterwork, the Institutes of the Laws, between 1628 and 1644 (with several parts published posthumously), and he is often described as the most influential common law jurist in English history. His work is widely seen as an authoritative survey of the common law prior to the Glorious Revolution. See, e.g., John F. Stinneford, The Original Meaning of "Unusual": The Eighth Amendment as a Bar to Cruel Innovation, 102 Nw. U. L. REv. 1739, 1771 (2008) ("Edward Coke has been described as the most important common law jurist in English history.").

${ }^{41}$ For homicide, it was not enough simply to mention the crime pardoned. The King also had to specify details about how the murder was accomplished. To understand the reason for this added specificity requirement, a bit of historical background is needed. Under the English common law, murder was an expansive doctrine. All killings were treated as murder punishable by death, no matter how the killings were carried out. Thus, not only where intentional killings treated as murder, but so were killings that were carried out in self-defense or caused accidentally. See Duker, supra note 9, at 479 ("Many of the defects in the practice of pardoning rested in the criminal justice system of which it was a part. Prior to the sixteenth century, the common law treated all homicides as felonies. In a society with no other means of flexibility, the pardon served as the sole instrument of justice for those who should not be punished." (footnote omitted)). For the latter types of homicides, a defendant's only relief would come from the King through a pardon. The common law wanted to discourage pardons for murders carried out without such mitigation, those accomplished by "[lying in] []wait, [a]ssault, or [m]alice prepense." Id. at 479,485 . The common law courts anticipated that, by requiring the King to articulate the kind of homicide, it would deter the King from giving pardons for these homicides, while leaving undisturbed the more deserving ones. 
"general") pardon for treason, rape, and murder. To do so, the King merely had to affirm that he was acting "non obstante"-notwithstandingParliament's law. ${ }^{42}$ The King, in short, had the power to suspend the law.

This power did not mean that the Pardon Act's restrictions were entirely meaningless. Rather, it meant that the King had to highlight the unusual nature of his conduct, by acknowledging he was acting contrary to the will of Parliament. The hope was that, by requiring the King to either specify the offense or announce his desire to suspend the law, the King would be deterred from issuing pardons for serious offenses, at least unless significant aggravating factors could be identified. Thus, as one commentator put it, "Parliament could not conceive that the king would ever pardon an offense by name that was attended by such aggravations." 43

The Pardon Act represents one of the first attempts to constrain the King's pardon powers. The requirement's limited scope reflected the weak position of the Parliament at the time of its passage. Parliament did not believe that it could bar the King outright from using general pardons. Instead, it adopted a narrow specificity requirement, hoping that specific disclosure of the offense would reduce the improper use of pardons, at least in the most serious cases. Over the next two centuries, Parliament occasionally attempted to restrict the King's pardon power further. ${ }^{44}$ These efforts, however, were largely ineffective and, over time, the King solidified his position as the dominant power in the Kingdom. ${ }^{45}$ His broad pardon authority reflected that lofty position. ${ }^{46}$ And yet, within a century, the balance of power in the Kingdom would be radically transformed.

${ }^{42}$ Edwardo Coke, The Selected Writings and Speeches of Sir Edward CoKe 424-25 (Steve Sheppard ed., 2003) [hereinafter SELECTED WritingS] (In enacting the statute, Parliament "knew that the King could not be restrained by any Act to make a Pardon; for mercy and power to Pardon is a Prerogative incident, solely and inseparably to the person of the King: And it hath oft-times been adjudged that the King can Pardon Murther by generall words without any expresse mention, with Non obstante, the said Statute, see 4 Hen. 4. cap. 31... . But in all such cases, although that the King may dispense with Statutes, yet a generall dispensation or grant without Non obstante is void.").

${ }^{43}$ Duker, supra note 9, at 485 . As Edward Coke suggested, a specificity requirement would deter such actions because publicity and transparency would increase the cost of making such pardons. Thus, Coke wrote, this was "the surest way that the Parliament could take to restrain the King to pardon Murther, unless that he Pardon it by express terms, which they thought the King would not." SELECTED WRITINGS, supra note 42, at 424.

${ }^{44}$ For example, in 1403, Parliament "enacted a statute affixing a financial penalty on the intermediary." Duker, supra note 9, at 485.

${ }^{45}$ More accurately, during this period, Parliament began to cede power to the King. In 1534, for example, Parliament passed the "Statute of Treason," which made it a crime to "deny the King's supremacy." Id. at $487 \mathrm{n} .60$. The next year, it enacted a statute that gave the King sole authority over pardons, precluding other institutions (such as the Church) from granting clemency. Id. at 486-87 (discussing a statute of 1535, which "solidified the king's jurisdiction over the power to pardon by removing the clemency power from all others"); Grupp, supra note 9, at 55 (same).

${ }^{46}$ Apart from the specificity requirement, only a few other constraints existed on the King's ability to grant mercy. For example, according to Coke, the King could pardon robberies, felonies against the peace, and homicide only by issuing the pardon by oath and specifying the name of those who offered 


\section{B. Lord Danby and L'Affaire Francaise}

The seventeenth century marked a period of intense turmoil in England over royal power. The battle played out as an institutional battle between the King and the Parliament, a conflict with significant religious and cultural overtones. The climactic events of the conflict, the Glorious Revolution of 1688 and the crowning of William of Orange the following year, were notable events in the emergence of Parliament as the dominant political institution in English society. ${ }^{47}$

Not surprisingly, the seventeenth and eighteenth centuries saw challenges to the King's use of the pardon power. The fight over pardons came to a head in the 1670s when several attempts were made to restrict the King's power to grant mercy. ${ }^{48}$ The most dramatic event, and the one most relevant for our discussion, occurred at the end of the 1670s. The central figure in the dispute was Thomas Osborne, Earl of Danby, who was the Lord High Treasurer of England.

Danby had the unfortunate luck to be at the center of an explosive intrigue involving King Charles of England and Louis XIV of France. To understand the Danby affair, one needs to have a sense of the deep antagonism at this time between many in Parliament and the Catholic King of France. The anti-French contingent in Parliament wanted to renew England's relationship with France's enemy, the Dutch Republic. Danby himself exhibited a strong anti-French orientation, seeing the Dutch Republic as the key to the expansion of English commerce.

King Charles of England, however, had a different agenda. In 1670, King Charles signed a secret treaty with Louis XIV (the "secret" Treaty of Dover), in which Charles pledged to aid the French in a planned attack on the Dutch. ${ }^{49}$ In addition, Charles promised to convert to Roman Catholicism.

information to support the pardon (to guard against deception). If the information "be found untrue, the Charter shall be disallowed." COKE, supra note 40, at 236. More generally, Coke affirmed that any false information given to the King to obtain the grant of mercy would make the pardon void. Id. at 238.

${ }^{47}$ See Cox, supra note 34, at 595 ("Stuart England was enmeshed in a century-long struggle between 'parliamentary supremacy' and 'absolutism.' To achieve absolute rule, the Crown sought better constitutional abilities to control Parliament, to rule legally without Parliament, and to crush Parliament militarily. After the Glorious Revolution, Parliament enacted statutes, adopted rules and began practices that blunted all three prongs of absolutist strategy. .. Cumulatively, constitutional engineering after the Revolution pushed parliamentary supremacy much more than anything that had been tried before, because it pushed that project on all three defensive fronts simultaneously.").

${ }^{48}$ For example, in 1673, a judicial tribunal held that the King was barred from pardoning offenses, such as nuisances, that led to continuing harms to private parties. Duker, supra note 9, at 486. In 1679, Parliament enacted the Habeas Corpus Act, which among other things prohibited anyone from causing an offender to be transported outside the realm (to undermine the offender's ability to seek habeas). The King was barred from granting clemency to violators of the rule. Grupp, supra note 9, at 57.

${ }^{49}$ Clare Jackson, Charles II: The Star King 31 (2016); Mark Kishlansky, The Penguin History of Britain: A Monarchy Transformed, Britain 1630-1714, at 245 (6th ed., Penguin Books 1997) (1996). 
In return, the French King committed to pay Charles 230,000 pounds per year. ${ }^{50}$

The result was a new war between England and the Dutch (the third Anglo-Dutch War). The war erupted in 1672 when the French and English fleets joined together to attack the Dutch state. Though the start of the war seemed promising for England, the Anglo-French alliance ultimately suffered serious strategic setbacks. ${ }^{51}$ As the war turned, public opinion began to sour on King Charles, stoked by growing suspicions that Charles was working with France to reverse Protestant domination in England. Fearing that his position was becoming untenable, King Charles agreed to terminate the war effort. In 1674, the English and Dutch signed a peace treaty ending their hostilities. ${ }^{52}$

Rather than break off his secret French ties, however, King Charles decided to use the growing anti-French fervor as leverage to ask King Louis for an increase in his support payments. ${ }^{53}$ In return for the additional funds, the King promised ongoing English neutrality and the suspension ("prorogation") of Parliament. ${ }^{54}$ Danby was an awkward choice to lead this mission, given his past opposition to the French. ${ }^{55}$ Nonetheless, Danby agreed to fulfill his duty on behalf of the King.

Ultimately, the secret negotiations between Danby and the French King broke down, due at least in part to Danby's intransigence in negotiations. ${ }^{56}$ King Louis retaliated by acquiring — and then disclosing — one of Danby's secret letters discussing the agreement between the two Kings. ${ }^{57}$

${ }^{50}$ R. Hutton, The Making of the Secret Treaty of Dover, 1668-1670, 29 HIST. J. 297, 303 (1986). Louis XIV also agreed to pay Charles 160,000 pounds for the public profession of his Catholicism. Id. To put this amount in perspective, in 1667, "the regular revenue of the crown yielded less than $900,000 . "$ Id. at 304.

${ }^{51}$ KISHLANSKY, supra note 49, at 246.

52 C. R. Boxer, Some Second Thoughts on the Third Anglo-Dutch War, 1672-1674, 19 TRANSACTIONS ROYAL HiST. SOC'Y 67, 91 (1968).

${ }^{53}$ For background on these machinations, see Clyde L. Grose, Louis XIV's Financial Relations with Charles II and the English Parliament, 1 J. MOD. HIST. 177, 195-97 (1929). See also 42 OsBORNE, DiCTIONARY OF NATIONAL BIOGRAPHY 297 (Sidney Lee ed., London, Smith, Elder \& Co. 1895).

${ }^{54}$ E. R. Edwards, Montagu, The History of Parliament: The House of Commons 1660-1690, HiST. PARLIAMENT, https://www.historyofparliamentonline.org/volume/1660-1690/member/montagu-ralph1638-1709 (last visited Oct. 9, 2019) [hereinafter Montagu].

${ }_{55}$ A. M. Evans, The Imprisonment of Lord Danby in the Tower, 1679-1684, 12 TRANSACTIONS ROYAL HiST. SOC'Y 105, 106-07 (1929).

${ }^{56}$ See Grose, supra note 53, at 184-93 (discussing Danby's role in the negotiations between the two monarchs).

57 The details of how the letter was obtained are complicated. After receiving the King's instructions, Danby apparently wrote a secret letter to Montagu, the English minister at the Court of Versailles. The letter "empower[ed] [Montagu] to make an offer of neutrality for the price of 6,000,000 livres.” 2 Henry Hallam, The CONSTitutional History of England, From the ACCESSiON of HENRY VII TO THE DEATH OF GEORGE II 410 (London, John Murray 8th ed. 1855). Montagu understood the importance of secrecy, and he responded to Danby by affirming, "You may be confident of my secrecy about this whole affair ... both for the King's, your lordship's and my own sake, for it would be 
As Louis expected, Parliament was furious at the duplicity of this arrangement and immediately resolved on Danby's impeachment. Though the letters were clearly issued at the King's direction, Danby was a much safer target than the King. ${ }^{58}$ Some contend that the impeachment "establish[ed] the principle that no minister can shelter himself behind the throne by pleading obedience to the orders of his sovereign." ${ }^{59}$ But a more accurate appraisal might be that the action reflected the fact that the King was untouchable, so a more vulnerable substitute would have to be punished in his stead.

Danby's impeachment was just the beginning of the saga. Under British law, impeachment could include not just removal from office, but criminal penalties. ${ }^{60}$ The Lords thus met to decide whether Danby deserved bail and whether his crimes should be treated as a misdemeanor or felony. ${ }^{61}$ King Charles pushed back, issuing Danby a pardon and, later, dissolving Parliament. ${ }^{62}$ Members of Parliament reacted furiously, questioning the King's authority to protect his minister in an impeachment proceeding. ${ }^{63}$

The dispute triggered a major conflict over the King's power to exercise the pardon. Although no rule barred the King from granting a pardon in an impeachment proceeding, Parliament remained firm, declaring the pardon illegal and demanding judgment against Danby (now imprisoned in the Tower of London). ${ }^{64}$ The result was a kind of constitutional crisis: a standoff between Parliament and the King. The impasse would last five years. Danby would spend most of that time in the Tower of London. ${ }^{65}$ The crisis did not fully resolve itself until King Charles' unexpected death in 1685 and the subsequent coronation of James II. Danby's sentence was then reversed, and

no popular or creditable thing if it were known." Montagu, supra note 54. Nonetheless, Montagu became angry after Danby failed to support his efforts to obtain higher office. After receiving compensation from the French, Montagu brought to public attention the letters Danby wrote arranging payments from Louis to Charles. 42 OSBORNE, supra note 53, at 298.

${ }^{58}$ The King's ultimate responsibility for the letters was plain. At the bottom of each letter was the King's own handwriting: "This letter is writ by my order, C.R." ChARLES KNIGHT, POPUlaR History OF ENGLAND 245 (1880). In addition, Charles himself testified before the House of Lords that Danby was acting on the King's command. See Duker, supra note 9, at 488.

${ }^{59} 2$ HALLAM, supra note 57, at 411.

${ }^{60}$ RULING CASE LAW, supra note 15, at 536 ("In England, the judgment on impeachments is not confined to mere removal from office, but extends to the whole punishment attached by law to the offense. The House of Lords, therefore, on a conviction, may, by its sentence, inflict capital punishment; or perpetual banishment; or forfeiture of goods and lands; or fine and ransom; or imprisonment, as well as removal from office, and incapacity to hold office, according to the nature and aggravation of the offense.").

${ }^{61} 2$ HALLAM, supra note 57 , at $412-13$.

${ }^{62}$ Id. at $414-15$.

${ }^{63}$ Duker, supra note 9, at 489-90.

${ }^{64} \mathrm{Id}$. at 493 ("No act on the statute books limited the royal attribute of mercy in cases of impeachment.").

${ }^{65}$ Danby remained "untried [and the] impeachment was never resumed." Id. at 495. He was released on bail from the Tower of London in 1684. Evans, supra note 55, at 133. 
Parliament was reinstated. ${ }^{66}$ Even then, Parliament continued to assert that the original pardon was invalid. ${ }^{67}$ It would soon take steps to ensure that the King would never again use a pardon to protect his ministers from impeachment.

\section{Royal Prerogatives After the Glorious Revolution}

The conflict between the King and Parliament was, on one level, an institutional dispute with foreign relations implications. But it played out within a broader religious conflict between Protestants, who dominated Parliament, and a Royal family who was thought - accurately-to harbor Catholic sympathies. ${ }^{68}$ That broader religious and cultural conflict came to a head in 1688, when King James' Catholic wife, Queen Mary, gave birth to a Roman Catholic son and heir, James Francis Edward. ${ }^{69}$

The possibility of a Catholic dynasty triggered a backlash. ${ }^{70}$ Seeking to restore Protestant control, influential protestants (including Danby himself) invited William of Orange to invade England. The Glorious Revolution, as it was called, culminated in 1689 with the crowning of William and his wife, Mary II, as the joint sovereigns of England. ${ }^{71}$

The Glorious Revolution undermined the idea of the divine right of Kings and led to the establishment of legal limits on the King's power, including new limits on the pardon power. In 1689, Parliament enacted the English Bill of Rights. Among other things, the Bill of Rights provided that the King could not suspend laws adopted by Parliament. One implication was that any restriction already in force was now binding and could not be set aside by the King ruling "non-obstante." As a result, the King could no longer suspend the old Pardon Act's specificity requirement for murder, rape, and treason. ${ }^{72}$ Thus, the Bill of Rights "had an indirect effect [on pardon power] when it prohibited the granting of dispensations, that is, by

\footnotetext{
${ }^{66}$ Evans, supra note 55, at 134-35.

${ }^{67} \mathrm{Id}$.

${ }^{68} 4$ Charles Knight, The Popular History OF ENGLAND 208 (New York, John Wurtele Lovell 1st ed. 1880) (discussing religious beliefs of Charles and his brother, James); JOHN MILLER, JAMES II 57-58 (2000) (discussing James' religious beliefs).

${ }^{69}$ Tim Harris, Revolution: The Great Crisis of the British MonARCHY, 1685-1720, at 1-3 (2007).

${ }^{70}$ Until that point, the Catholic sympathies of King Charles and King James seemed a speculative threat to the Protestant majority. Had Queen Mary died without a son, King Charles' eldest sister, Mary Stuart, would have been handed the Crown. Mary was a Protestant, as well as wife of William of Orange. With James' birth, it was clear that a Catholic line of Kings was now possible. See id. at 271-72.

${ }^{71} I d$. at 321 .

${ }^{72}$ This was but one part of the English Bill of Rights' limitations on the King's power. The Act also barred the King from, among other things, "levying money [i.e. taxes] . . . without grant of parliament," "raising or keeping a standing army within the kingdom in time of peace," and interfering with the "election of members of parliament." An Act for Declaring the Rights and Liberties of the Subject and Settling the Succession of the Crown (Bill of Rights) 1689, 1 W. \& M. c. 2, 7 (Eng.).
} 
declaring it illegal for the Crown to claim . . . the right to disregard the law in the execution of a particular case." 73

The Bill of Rights also meant that binding restrictions could be imposed upon the King by Parliament or judicial decision. In 1701, Parliament passed the Act of Settlement, which revisited the issue raised in the Danby case: whether the King had the power to pardon an official in an impeachment hearing. The Act of Settlement explicitly declared that pardons could not be made to insulate an official from being removed from office through impeachment. The King could still issue a pardon to insulate the impeached minister from any criminal penalties that might be imposed during the proceeding, but that would be the extent of his powers. ${ }^{74}$ Thus, if a pardon was granted, the official would lose his position but not his liberty.

\section{The Specificity Requirement and the Common Law}

The Act of Settlement was a substantive restriction on the pardon power, in that it excluded a category of cases - impeachment rulings - from the reach of the pardon power. But other "procedural" restrictions were also recognized. Identifying the nature of these restrictions is not as easily described, since the restrictions were not incorporated into a statute. Rather, the scope of the pardon power can only be identified through a careful reading of what John Yoo has called the "English Constitution." That Constitution, of course, was not written down, but was comprised "of a series of unwritten principles, expressed in practice, statutes, and understandings" that existed at the time. ${ }^{75}$

The Framers, in assessing the scope of the pardon power, would have referred to this body of law. Specifically, they would have looked to leading legal authorities of the common law to provide insight into the nature of those procedural restrictions. The legal rules distilled from these authorities would thus have "formed the context within which the Framers would have understood the new Constitution.","76

\footnotetext{
${ }^{73}$ Grupp, supra note 9, at 57 .

${ }^{74}$ RULING CASE LAW, supra note 15, at 535 ("'I]n 1700 the act of settlement . . . declared 'that no pardon under the great seal of England be pleadable to an impeachment by the Commons in Parliament.' ... [But there] is no doubt that the king can pardon after sentence on an impeachment."); THOMAS PITT Taswell-Langmead \& Charles Henry Edward Carmichael, English Constitutional History From the Teutonic Conquest to the Present Time 529 (London, Stevens \& Haynes 3d ed. 1886) ("The Act of Settlement ... declared 'that no pardon under the Great Seal of England shall be pleadable to an impeachment by the Commons in Parliament.' The right of the Crown to reprieve or pardon after sentence, remains, however, unaffected."); Duker, supra note 9, at 503 n.152 ("In English law, although the king could not pardon to block an impeachment, he could pardon subsequent to impeachment and conviction."); Grupp, supra note 9, at 57 ("In 1701 the Act of Settlement prohibited the use of pardon in cases of impeachment although it did not prohibit its use after the impeachment had been heard.").

${ }^{75}$ YoO, supra note 33 , at 31.

${ }^{76} \mathrm{Id}$.
} 
Several notable authorities discussed the common law of pardons in the early eighteenth century in some depth. Of these, the most notable was William Blackstone, the most influential authority on the common law at this time. ${ }^{77}$ Blackstone lived from 1723 until 1780 and published his classic work, the Commentaries, in the decades before the Constitution was adopted. $^{78}$ The Framers were deeply familiar with his work, and key members of the Constitutional Convention were known to have copies of the Commentaries in their immediate possession. Among political writings in America during the founding period, Blackstone was far and away the most frequently cited authority on the common law. ${ }^{79} \mathrm{He}$ was also among the most cited common law authorities in the Supreme Court's major decisions interpreting the scope of the Pardon Clause. ${ }^{80}$

In the Commentaries, Blackstone offers a clear statement about the necessity of naming the particular offense to be pardoned. As he wrote: "General words have ... a very imperfect effect in pardons. A pardon of all felonies will not pardon a conviction ... (for it is presumed the King knew not of those proceedings,) but the conviction . . . must be particularly mentioned." ${ }^{\prime 81}$ Blackstone's statement is broad, and it lists no exceptions. It applies to convictions of all felonies and not simply the most serious crimes mentioned in the Pardon Act of $1389 .{ }^{82}$

77 Schick v. United States, 195 U.S. 65, 69 (1904) (“Blackstone's Commentaries are accepted as the most satisfactory expression of the common law of England. At the time of the adoption of the Federal Constitution it had been published about twenty years, and it has been said that more copies of the work had been sold in this country than in England, so that undoubtedly the framers of the Constitution were familiar with it."); see also Yoo, supra note 33, at 312 n.16 ("Blackstone's Commentaries had great appeal for the founding generation as the authoritative treatise on many areas of law.") (citing GoRDON S. WOOD, THE CREATION OF THE AMERICAN REPUBLIC 1776-1787, at 10 (1969)).

${ }^{78} 1$ WiLliam Blackstone, COMMENTARIES ON THE LAWS OF ENGLAND (Oxford, Clarendon Press $1765)$.

79 Donald S. Lutz, The Relative Influence of European Writers on Late Eighteenth-Century American Political Thought, 78 AM. POL. SCI. REV. 189, 194 (1984). The only other common law authority in the top ten is Edward Coke (at number ten), who wrote in the seventeenth century, before the Glorious Revolution. Id. Among all Enlightenment thinkers mentioned in these political writings, Blackstone is ranked second, trailing close behind Montesquieu. Id.

${ }^{80}$ See, e.g., Ex parte Grossman, 267 U.S. 87, 111-12 (1925); Schick v. United States, 195 U.S. 65, 69 (1904); Ex parte Garland, 71 U.S. (4 Wall.) 333, 381 n.52 (1866); Ex parte Wells, 59 U.S. (18 How.) 307, 311 (1855); United States v. Wilson, 32 U.S. (7 Pet.) 150, 162-63 (1833).

814 WiLliam BLACKSTONE, COMMENTARIES ON THE LAWS OF ENGLAND *393 (1769).

${ }^{82}$ The Pardon Act of 1389, however, is still operational in one respect. As noted earlier, see supra text accompanying note 41, the Pardon Act requires the King not only to specify the offense being pardoned but, at least for murder, to describe the specific way it was carried out. Blackstone clearly recognized this feature of the Pardon Act. See 4 BLACKSTONE, supra note 81, at * 400 ("[N]o pardon for treason, murder, or rape shall be allowed unless the offence be particularly specified therein; and particularly in murder it shall be expressed whether it was committed by lying in wait, assault, or malice prepense.”). This feature of the Pardon Act does not appear to have been repealed. As a result, after the English Bill of Rights was adopted, it was binding on the King. In this way, the specificity requirement was actually two-tiered. For ordinary felonies, the King must specify the particular crime being pardoned. For the more serious crime of murder, and possibly treason or rape, a "super-particularity" requirement 
Blackstone may be the most influential common law authority of the eighteenth century, but he is not the sole authority of note. Another was William Hawkins (1673-1746), who published his major work, Pleas of the Crown, in $1716 .{ }^{83}$ Like Blackstone, Hawkins recognized the existence of a specificity requirement. "It seems to be taken for granted," he wrote, that a pardon can be issued for "all Felonies in general, without describing any one particular Felony." ${ }^{\prime 4}$ But such a belief, Hawkins continues, is in error, for: "[I]t hath been holden that the pardon of one who is convicted by verdict of a felony is not good, unless it recite the indictment and conviction." 85

Other lesser-known authorities on the common law published works in the eighteenth century, which also affirmed that the King must specify the offense pardoned. For example, Jacob Giles published his major work, the Student's Companion: Or, The Reason of the Laws of England, in 1725. There, Giles acknowledged that, for the grant of mercy to be valid, "[t]he offense is to be specified in pardons." ${ }^{86}$ Thomas Wood's treatise, An Institute of the Laws of England, went through ten editions between 1720 (when it was first published) and $1774 .{ }^{87}$ In that work, he wrote that, "A general pardon of all murders, robberies, etc. to one indicted and convicted of murder, robbery, etc. is not good, without recital of the indictment and conviction. For it shall be intended that the King knew not of that conviction. $"{ }^{" 88}$ The bottom line is that, according to leading authorities at the

applied. The King not only had to specify the crimes to be pardoned, he also had to specify the general way in which the crimes were carried out.

${ }^{83} 1$ William Hawkins, A Treatise of the Pleas of the Crown: Or a System of the Principal Matters Relating to that Subject, Digested Under Their Proper Heads (1716). Like Blackstone, Hawkins was one of the most frequently cited common law authorities in Supreme Court decisions on the scope of the Pardon Clause. See, e.g., Ex parte Grossman, 267 U.S. 87, 111 (1925); Ex parte Garland, 71 U.S. (4 Wall.) 333, 381 n.52 (1866); Ex parte Wells, 59 U.S. (18 How.) 307, $311-$ 12 (1855); United States v. Wilson, 32 U.S. (7 Pet.) 150, 161-62 (1833).

${ }^{84} 1$ HAWKINS, supra note 83 , at 383 . Note that here and elsewhere I have corrected common law spelling and capitalization to conform with modern usage (e.g., I have changed " $\mathrm{f}$ " to "s" where appropriate).

${ }^{85} \mathrm{Id}$.

${ }^{86}$ Giles Jacob, The Student's Companion: OR, the Reason of the LaWs OF ENGLAND 140 (1725) ("The King, by the Common Law, had Power to Pardon all Offences; but this Power hath been restrained by Statute, particularly in Cases of Murder. He may still Pardon Treason, Felony, Manslaughter, Crimes and Misdemeanors, and Fines and Forfeitures incurr'd by such Offences; And the King may also Restore Corruption of Blood to the Family of the Offenders, by his Act of Pardon. But in Cases of Wilful Murder, to Pardon an Offender is contrary to the Laws of God and Man; And where an Appeal may be brought by the Subject, by the Laws of England, a Murderer could never be Pardon'd.").

Interestingly, Jacob concludes that in the case of homicide, the King is absolutely barred from pardoning murder absent a showing of self-defense or accident (i.e., it is not sufficient to specify with particularity how the murder occurred). See id. ("Our Statutes enjoin that no Charter of Pardon be Granted for Murder, but only where one Killeth another in his own Defence, or by Misadventure.").

${ }^{87}$ All citations here are to the Fourth Edition (corrected), which was published in 1724. THOMAS WOOD, AN INSTITUTE OF THE LAWS OF ENGLAND (J. Watts corrected ed. 1724).

${ }^{88} I d$. at 636 . Elsewhere, he makes the seemingly contradictory claim the King may, under some circumstances, issue general pardons. See id. at 637 ("Pardons . . . are either General or Particular. 
time, a specificity requirement existed in the common law. As a result, pardons that failed to specify the applicable offenses were deemed invalid.

On what basis was the specificity requirement adopted? The common law authorities were not always clear on the matter. One factor, certainly, was the historical practice at the time. As Hawkins noted, vague and general pardons were exceedingly rare in the common law. Those issued were either of older origin, or made by an Act of Parliament, not the King. ${ }^{89}$

Legal practice alone, however, did not ground the specificity requirement. The requirement was seen, in part, as a natural extension of rules designed to curb the accidental or abusive use of pardons. ${ }^{90}$ Most obviously, it was a direct extension of the Pardon Act of 1389 itself. That Act, recall, required the King to announce when he was pardoning a serious crime, like murder. ${ }^{91}$ The rule was understood to serve a deterrence goal; it would dissuade the King from issuing pardons for illicit or improper motives. ${ }^{92}$ Of course, the Pardon Act was limited in scope: it applied only to

General, either by the Act of Parliament or By Charter of the King."). But that statement can be reconciled with the ban on vague pardons by construing the support for general pardons to apply only to preemptive pardons-pardons made before indictment. See id. at 636 ("But if the Party is neither indicted or Attainted, A Pardon of all Felonies in General (except as the Statute of Rich. 2 above-mentioned is excepted) is Good.").

${ }^{89} 1$ HAWKINS, supra note 83 , at 384 (General pardons "have been of late Years very rarely granted by the Crown, without a particular Description of the Offence intended to be pardoned."). Hawkins recognizes that some contrary precedents can be found in ancient collections of cases, but that these have been superseded by more recent practice. 2 William Hawkins, A TREATISE OF the Pleas of the Crown: Or, A System of the Principal Matters Relating to that SubJect, Digested Under PROPER HEADS 535 (London, Law Booksellers and Publishers, 8th ed. 1824). Hawkins continues:

As to the Precedents of such general Pardons in Rastal's Entries [a collection of fifteenth century cases], it may be answered, that their Authority seems to be of less weight when compared with those many precedents of pardons in the Register, every one of which particularly describes the offence which is pardoned, and even those which relate to homicide by lunatics, or infants, or in self-defence, etc. except only one which pardons escapes, but expressly excepts all voluntary ones. And therefore where the books speak of pardons of all felonies in general as good, perhaps it may be reasonable for the most part to intend that they either speak of a pardon by parliament, or that they suppose that the particular crime is mentioned in the pardon, though they do not express it.

Id.

${ }^{90}$ Deterring the accidental and abusive employment of pardons has long been seen as the core goal of the specificity requirement. As one American court put it, there has always been a specificity requirement for two basic reasons: "(1) to assure that the pardon will be given effect only with respect to the offense intended to be pardoned, and (2) to protect the citizenry against executive irresponsibility." Fletcher v. Graham, 192 S.W.3d 350, 386 (Ky. 2006).

${ }^{91} 4$ BLACKSTONE, supra note 81 , at $* 400$.

${ }^{92}$ Blackstone, citing Coke, explained that in adopting the Pardon Act, "it was not the intention of the parliament that the king should ever pardon murder under these aggravations; and therefore they prudently laid the pardon under these restrictions, because they did not conceive it possible that the king would ever excuse an offence by name, which was attended with such high aggravations. And it is remarkable enough, that there is no precedent of a pardon in the register for any other homicide than that 
the most serious crimes (and it was limited in its effect, since the King could suspend the rules).$^{93}$ These limitations reflected Parliament's limited powers to control the King's authority prior to the Glorious Revolution. Nonetheless, as Parliament gained the upper hand over the King, it was natural to expand the scope of the rule. If specificity could deter abusive pardons for serious crimes, why not expand it to the full range of felonies? The specificity requirement of the eighteenth century thus strengthened the deterrence effect, applying the rule to all crimes, not just the most serious ones.

This was not the only basis for an expanded specificity requirement. Under long-held common law principles, a pardon would be deemed void if it could be shown that the King was uninformed, misinformed, or deceived about the facts of a case. ${ }^{94}$ This rule reflected the basic idea that only a pardon given intentionally, with full knowledge of the circumstances, is valid. $^{95}$

A broad specificity requirement was seen as a useful prophylactic rule to counter the danger of an unintentional pardon. A vague, non-specific pardon, for example, might be employed to vacate crimes that were not within the King's contemplation or intent. Thus, in defending the specificity requirement, Hawkins wrote, "where the king in truth intends only to pardon one felony, which may be very proper for his mercy, he may by consequence pardon the greatest number of the most heinous crimes, the least of which, had he been apprised of it, he would not have pardoned." 96 To avoid the danger of unintended pardons, a royal decree of mercy must be construed narrowly. ${ }^{97}$ It must be limited to crimes expressly mentioned in the pardon. ${ }^{98}$

which happens se defendendo [in self-defense] or per infortunium [by accident] . ..." Id. at *400-01.

${ }^{93} I d$. at $* 400$.

${ }^{94}$ See 4 BLACKSTONE, supra note 81 , at *400 ("[I]t is a general rule that wherever it may reasonably be presumed the king is deceived, the pardon is void. Therefore any suppression of truth, or suggestion of falsehood, in a charter of pardon will vitiate the whole; for the king was misinformed."); 2 HAWKINS, supra note 89, at 557 (It "be agreed, That if it appears from the recital of a pardon, that the king was misinformed either as to the nature of the case, or the proceedings thereupon, the pardon is void; as where the king pardons a man for felony whereof he stands indicted, or indicted and attainted, and in truth he never was indicted ....").

${ }^{95}$ See 2 HAWKINS, supra note 89, at 542 ("It seems to be laid down as a general rule in many books, that wherever it may be reasonably intended that the king, when he granted such pardon, was not fully . .. apprised both of the heinousness of the crime, and also how far the party stands convicted thereof upon record, the pardon is void, as being gained by imposition upon the king.").

${ }^{96} I d$. at 543.

${ }^{97}$ Hawkins made clear that the specificity requirement was grounded on this rule against uninformed pardons. As he writes, any claim that general pardons are permissible is not "easy to reconcile with the general rules concerning pardons, agreed to be good in other cases; for if a felony cannot be well pardoned where it may be reasonably intended that the king, when he granted the pardon, was not fully apprised of the state of the case, much less doth it seem reasonable that it should be pardoned where it may be well intended that he was not apprised of it at all." Id. at 534 .

${ }^{98}$ See id. at 535 ("It seems a settled rule, that no pardon of felony shall be carried farther than the express purport of it ...."). 
The specificity requirement, in short, advanced goals already embedded in the common law-goals designed to reduce the number of abusive and accidental pardons issued by the King. Those goals existed in limited form in the common law prior to the eighteenth century, reflecting the King's dominant position in English society during that time. But as the King's power declined, the dangers of an unfettered pardon power could be more openly addressed. Rather than a kingly prerogative, the pardon power could be seen as an extraordinary remedy that posed a danger to the public interest by its careless or, worse, abusive employment. An expansive specificity requirement was one key remedy, and it applied to all felonies without exception. ${ }^{99}$

\section{E. The Common Law and the Constitution}

The common law provides strong support for a specificity requirement, especially in light of the Supreme Court's originalist approach to the pardon power. But support for the requirement is further buttressed by the recognition that the pardon power sits awkwardly within America's constitutional scheme. Without appropriate limitations, the pardon power conflicts with democratic values, rule of law principles, and due process concerns that lie at the heart of the constitutional order.

The tension with democratic values is plain. The American revolution represented a decisive break with monarchy. ${ }^{100}$ The ultimate source of authority in the new nation would be the people, not the King. Pardons, in this context, are out of place, authorizing the executive to override the will of the people. As one author explained, "[i]n a monarchy, a crime is a crime against the King, who alone has the power to pardon. But in a democracy, a crime offends against the people. Who can pardon a crime, then, except the people themselves?"101 It is precisely for this reason that many early and influential commentators, including Montesquieu and Blackstone, raised questions about the compatibility of the pardon power with democracy. ${ }^{102}$

\footnotetext{
${ }^{99} \mathrm{Of}$ course, in assessing the common law, nothing is entirely free from doubt. The precise meaning of terms is not always clear to us, and at least one case from immediately before the Glorious Revolution suggests that non-specific pardons might be sufficient. See Dominus Rex \& Brownfield, Pardon, in 84 THE ENGLISH REPORTS: KING'S BENCH Division 853 (Edinburgh, William Green \& Sons 1908) (1685) ("The Court . . . conceived that a general pardon of all felonies and burglaris . . is sufficient, without particular recital of the indictment, which was mistaken ... and the pardon was allowed."). But the vast weight of opinion - including leading writers like Blackstone and Hawkins - indicates that a specificity requirement existed in the common law at the time of the Constitution's drafting.

${ }^{100}$ See, e.g., 1 Thomas Paine, The Writings of Thomas Paine 70 (Moncure Daniel Conway ed., New York, G.P. Putnam's Sons 1894) ("But where, say some, is the King of America? I'll tell you, friend, he reigns above, and doth not make havoc of mankind like the Royal Brute of Great Britain. ... For as in absolute governments the King is law, so in free countries the law ought to be king; and there ought to be no other." (emphasis added)).

${ }^{101}$ Kathleen Dean Moore, Pardons: Justice, Mercy, and the Public Interest 24 (1997).

${ }^{102}$ For example, William Blackstone wrote that, "In democracies, . . . this point of pardon can never
} 
Beyond its potentially undemocratic features, an unfettered pardon power also conflicts with rule of law values. Those values require laws to be publicly articulated, clearly defined, and applied consistently across society. An unregulated pardon power undermines these goals. As one commentator put it, such a power represents not so much discretionary justice, but justice in "derogation of law." 103 The danger of an unchecked discretionary power would have been plain to the Framers, who fought to counter the arbitrary or abusive power of English Kings.

Finally, and more narrowly, vaguely-drafted pardons undermine due process principles. As the Supreme Court has indicated, acceptance of a pardon represents the acknowledgement of guilt. ${ }^{104}$ In ordinary criminal cases, due process requires the defendant to know the crimes he is pleading guilty to. Thus, a court will refuse to accept a guilty plea without making sure "the plea is made voluntarily with understanding of the nature of the charge" and the consequences of the plea. ${ }^{105}$ The same principle extends to pardon cases. A defendant must know the specific crimes he is admitting to when utilizing a pardon.

These concerns illustrate the anomalous position that the pardon power has in our constitutional scheme. This is not to conclude that pardons are without all justification. The Framers understood that pardons could be employed for public-spirited purposes, to grant mercy to deserving offenders or to mitigate the harsh consequences of criminal laws. ${ }^{106}$ It is for these reasons that the Constitution grants the President authority to issue pardons in the first place. But the tension with democratic, rule of law, and due process principles means that pardons are properly seen as extraordinary

subsist; for there nothing higher is acknowledged than the magistrate who administers the laws: and it would be impolitic for the power of judging and of pardoning to centre in one and the same person." 4 BLACKSTONE, supra note 81, at *397. Montesquieu, one of the most influential theorists of the founding period, made a similar point. See MOORE, supra note 101, at 24 ("In France, for example, Montesquieu made it clear that he had no objection to pardons in principle. In fact, they could be useful as a way of making the punishment fit the particular crime. But in a republic, Montesquieu declared, there could be no pardon.”). Montesquieu was the most cited theorist among the Framers during the period leading up to the constitutional debates. See Lutz, supra note 79, at 193 (listing Montesquieu as the most cited political theorist among those mentioned in the Framers' writings).

${ }^{103}$ As one treatise author wrote, "Pardons, being in derogation of law, to be valid and of effect must accurately describe the offense intended to be forgiven." RULING CASE LAW, supra note 15, at 548.

${ }^{104}$ Burdick v. United States, 236 U.S. 79, 94 (1915). See also 11 Op. Att'y Gen. 227, 228 (1865) ("There can be no pardon where there is no actual or imputed guilt. The acceptance of a pardon is a confession of guilt, or of the existence of a state of facts from which a judgment of guilt would follow.").

${ }^{105}$ See Brady v. United States, 397 U.S. 742, 744 n.3 (1970) (quoting FED. R. CRIM. P. 11) ("The court may refuse to accept a plea of guilty, and shall not accept such plea ... without first addressing the defendant personally and determining that the plea is made voluntarily with understanding of the nature of the charge and the consequences of the plea.").

${ }^{106}$ The Framers certainly understood the benefit of mercy in select cases. Alexander Hamilton emphasized that ameliorating the harshness of the laws was one argument for the pardon power; the need to reconcile combatants through well-timed amnesties was another. THE FEDERALIST NO. 74 (Alexander Hamilton). 
remedies. It also means that modest rules that can help counter abusive, haphazard, and unintentional pardons are fully consistent with this constitutional structure.

In this regard, the specificity requirement is a well-tailored tool for mitigating the most problematic features of the pardon power, while preserving a broad sphere for the exercise of executive discretion. As a preliminary matter, the requirement does not establish substantive limitations on the kinds of offenders or the types of crimes that might be pardoned, thereby leaving a wide field for the President. At the same time, the requirement helps to counteract some of the worst excesses of the power.

By requiring the President to identify the specific offenses pardoned, the requirement advances democratic values by providing the public and the political branches with critical information needed to evaluate the propriety of the pardon. The requirement promotes due process values by ensuring that defendants know what they are confessing to. And it promotes rule of law values by deterring the haphazard or abusive use of executive power. The requirement is, thus, carefully structured to advance constitutional values, without interfering with the pardon power's more benign goals. ${ }^{107}$

\section{OBJECTIONS}

The argument in support of a specificity requirement has been grounded on a careful reading of the common law and the Constitution's core values. The argument, however, potentially faces two objections- one based on the text of the Constitution, the other based on historical practice. Both warrant careful attention.

\footnotetext{
${ }^{107}$ One counterargument is that the Framers adopted a different remedy for abusive pardonsimpeachment. Unlike the King of England, an American President can be removed from office if he misuses the pardon power. Given the availability of presidential impeachment, this argument goes, additional curbs are unnecessary. This argument, which might be superficially plausible, is ultimately unpersuasive.

As a preliminary matter, there is no evidence that the Framers wanted impeachment to override the common law's prophylactic requirement. Given the Supreme Court's repeated statements that the pardon power incorporates common law limitations, one would expect some indication from the drafters that they intended to override the specificity requirement. There is no such evidence. Rather, the similarities in language between the English Act of Settlement and the Constitution's Pardon Clause suggests that the Framers sought to mirror British law and practice, not abolish common law limitations sub silentio. See Duker, supra note 9, at 501 (noting similarities in language).

Moreover, it is misguided to view impeachment as a substitute for the specificity requirement. Impeachment is an extreme remedy. It may deter Presidents from using the pardon power in the most egregious situations, but it does not address lesser misuses of the pardon power, nor does it address the danger that a broad, vaguely-worded pardon might apply beyond the President's intent. Most importantly, the specificity requirement, rather than conflicting with the impeachment mechanism, actually supports it. Since impeachment is principally a political remedy, it requires some ability for the political branches to police the executive. Transparency promotes that goal in publicity function. By exposing the scope of the pardon, the political branches can see what is being pardoned and can act accordingly.
} 


\section{A. The Textual Objection}

The first objection focuses on the language of the Pardon Clause itself. According to various commentators, the text of the Constitution reveals only two limitations: pardons cannot be used in impeachment cases or in state prosecutions. By identifying these two restrictions in the text, the Framers implied that none other exists. As John Yoo and Saikrishna Prakash affirm, the "text shows that the Framers knew how to make exceptions to the pardon power," and if they meant to impose any additional constraints, the Framers would have done so in the text. ${ }^{108}$

This argument faces several problems. The first is that it rests on a rule of statutory construction that is not a firm rule at all. The principle, called "expressio unius" in Latin, stands for the proposition that the expression of one thing suggests the exclusion of others. Thus, according to that rule, if two exceptions are listed in the text, the Framers intended no other limitations to apply.

The initial difficulty, as David Golove, has put it, is that "drawing the expressio unius inference can be a risky venture. In constitutional adjudication, the Court has sometimes applied the canon, but it has often explicitly rejected it." 109 Numerous other theorists have made similar points. ${ }^{110}$ Perhaps the most famous is Alexander Hamilton, who warned against using the maxim in an unthinking manner. ${ }^{111}$

More fundamentally, the Supreme Court has made it clear that the textual limitations were not intended to eliminate other "implicit" limits on the pardon power, including common law limits. ${ }^{112}$ To believe otherwise,

${ }^{108}$ John Yoo \& Saikrishna Prakash, For Trump, Self-Pardon Would Equal Self-Immolation, PHILA. INQUIRER (July 27, 2017, 5:00 AM), http://www2.philly.com/philly/opinion/commentary/for-trumpself-pardon-would-equal-self-immolation-20170727.html.

${ }^{109}$ David M. Golove, Against Free-Form Formalism, 73 N.Y.U. L. REv. 1791, 1815-16 (1998) (footnotes omitted). As Golove points out, numerous Supreme Court cases have rejected the rigid application of the rule. See id. at 1815 n.85 (collecting cases).

${ }^{110}$ See, e.g., Akhil Reed Amar, Some Opinions on the Opinion Clause, 82 VA. L. REV. 647, 65354 n.30 (1996) ("[T]he expressio unius maxim of inference by negative implication must be applied sensitively and contextually; sometimes a negative implication makes the most sense of a clause, sometimes not."); Myres S. McDougal \& Asher Lans, Treaties and Congressional-Executive or Presidential Agreements: Interchangeable Instruments of National Policy, 54 YALE L.J. 181, 237 n.99 (1945) ("The general view has been that the maxim of construction expressio unius est exclusio alterius has no validity as a canon of constitutional construction."); Laurence H. Tribe, Taking Text and Structure Seriously: Reflections on Free-Form Method in Constitutional Interpretation, 108 HARV. L. REV. 1221, 1273 (1995) (noting limitations of statutory rule).

${ }^{111}$ See THE FEDERALIST NO. 83 (Alexander Hamilton) (affirming maxim should only be used when reason and common sense suggest it is appropriate).

${ }^{112}$ See Schick v. Reed, 419 U.S. 256, 263-64 (1974) (“In light of the English common law from which such language was drawn, the conclusion is inescapable that the pardoning power was intended to include the power to commute sentences on conditions which do not in themselves offend the Constitution, but which are not specifically provided for by statute."). 
one would have to reject the Supreme Court's repeated statements that the Pardon Clause should be interpreted in light of common law practice. ${ }^{113}$

Ex parte Grossman offers one of the clearest statements to this effect. After discussing the English origins of the Pardon Clause, the Court affirmed the continuing validity of common law limits:

We have given the history of the clause to show that the words "for offences against the United States" were inserted by a Committee on Style, presumably to make clear that the pardon of the President was to operate upon offenses against the United States as distinguished from offenses against the States. It cannot be supposed that the Committee on Revision by adding these words, or the Convention by accepting them, intended sub silentio to narrow the scope of a pardon from one at common law or to confer any different power in this regard on our Executive from that which the members of the Convention had seen exercised before the Revolution. ${ }^{114}$

Moreover, application of expressio unius would run contrary to Supreme Court precedent, ${ }^{115}$ which has identified various implicit limitations on the Pardon Clause, including rules that a pardon must be accepted and then pleaded to be valid. ${ }^{116}$

${ }^{113}$ See, e.g., id. at 262 ("The history of our executive pardoning power reveals a consistent pattern of adherence to the English common-law practice."); Ex parte Grossman, 267 U.S. 87, 112 (1925) (discussing the "authoritative background of the common law").

${ }^{114}$ Grossman, 267 U.S. at 113. The rest of the Court's statement here deserves mention as well:

Nor is there any substance in the contention that there is any substantial difference in this matter between the executive power of pardon in our Government and the King's prerogative. The courts of Great Britain were called the King's Courts, as indeed they were; but for years before our Constitution they were as independent of the King's interference as they are today. The extent of the King's pardon was clearly circumscribed by law and the British Constitution, as the cases cited above show. The framers of our Constitution had in mind no necessity for curtailing this feature of the King's prerogative in transplanting it into the American governmental structures, save by excepting cases of impeachment; and even in that regard, as already pointed out, the common law forbade the pleading a pardon in bar to an impeachment. The suggestion that the President's power of pardon should be regarded as necessarily less than that of the King was pressed upon this Court and was agreed to by Mr. Justice McLean, one of the dissenting Judges, in Ex parte William Wells, 18 Howard, 307, 321 , but it did not prevail with the majority.

Id.

115 See Clifton Williams, "Expressio Unius Est Exclusio Alterius”, 15 MARQ. L. REV. 191, 193 (1931) (explaining the rule of construction that "the expression of one subject, object, or idea is the exclusion of other subjects, objects, or ideas").

${ }^{116}$ See United States v. Wilson, 32 U.S. (7 Pet.) 150, 155-56, 161 (1833) (“[T]he court cannot give the prisoner the benefit of the pardon, unless he claims the benefit of it, and relies on it by plea or motion. ... [A] general plea of not guilty, was equivalent to a refusal to accept it."). 
The Court has made it absolutely clear, in short, that the rule of statutory interpretation is inapplicable in the pardon context and that the pardon power is limited by both explicit textual restrictions and implicit common law rules. That view is the only one consistent with Supreme Court rulings and the text of the Constitution.

One might still wonder why the Framers included several textual limitations rather than relying entirely on common law practices. The most plausible explanation is that the Framers incorporated textual limitations in those cases where there were questions about the applicability of common law rules. Consider, for example, the textual provision restricting the pardon power to "offenses against the United States." 117 Absent that clause, uncertainty would exist about the applicability of the pardon power to state crimes, and reliance on the common law would yield no clear answer. The English system, after all, did not have a similarly structured federal system.

Given that potential ambiguity, the Framers quite reasonably concluded that a specific textual limitation would be needed to make clear that the pardon power did not extend to state crimes. Doing so did not signify a desire to preempt the common law; it simply reflected the realization that the common law was silent or ambiguous in this area.

A similar issue arises in the case of pardons during impeachment proceedings. Once again, without a textual limitation, the Pardon Clause would be unclear. ${ }^{118}$ The text would simply read: "The President shall have the Power to grant Reprieves and Pardons for Offenses against the United States." 119 The text, at least on one reading, would not prohibit the use of pardons in impeachment cases. True, the common law has something to say about this matter. The Act of Settlement bars the use of pardons to prevent an official's removal from office during impeachments. ${ }^{120}$ But the Act of Settlement does not prohibit the use of pardons during impeachment cases entirely. As noted earlier, the Act still permits the King to issue a pardon to

\footnotetext{
${ }^{117}$ U.S. CONST. art. II, § 2, cl. 1.

${ }^{118} I d$. ("[The President] shall have Power to grant Reprieves and Pardons for Offenses against the United States, except in Cases of Impeachment." (emphasis added)).

${ }^{120}$ Act of Settlement 1700, $12 \& 13$ Will. 3 c. $2, \S 3$ (Eng.), https://www.legislation.gov.uk/ aep/Will3/12-13/2 ("That no Pardon under the Great Seal of England be pleadable to an Impeachment by the Commons in Parliament.").
} 
vacate criminal penalties issued during impeachments, but pardons could not be used to bar removal from office. ${ }^{121}$

This nuanced common law rule reflected a unique feature of English impeachments. Those proceedings could result, not just to an official's removal from office, but in additional criminal penalties as well. ${ }^{122}$ This is quite different from the American system, where impeachments can only result in the removal from office (i.e., criminal penalties could not be authorized). ${ }^{123}$

Absent specific guidance in the text of the Constitution, one might plausibly contend that the common law rule did not apply to the American scheme, given the different outcomes in English and American impeachment proceedings. As a result, without a textual limit, the Constitution could be read to authorize the President to issue pardons in impeachment cases.

This may not be the most persuasive reading of how the Act of Settlement applies to the constitutional scheme. But it is at least a plausible reading. Given the potential for confusion, it made sense for the Framers to include explicit textual guidance in Article II about the validity of pardons in impeachment cases.

${ }^{121}$ The unique features of the royal pardon power were plainly understood by the Framers and were mentioned in the debates over the Pardon Clause. Duker, supra note 9, at 501. In one of the few exchanges on the pardon power at the Convention, James Iredell observed that, in England, the King's pardon "is not pleadable in bar of an impeachment. But he may pardon after conviction, even on an impeachment; which is an authority not given to our President, who in case of impeachments has no power either of pardoning or reprieving." Id. at 502 (quoting PAMPHLETS ON THE CONSTITUTION OF THE UNITED STATES 350-51 (P. Ford ed., 1968)).

The Framers took those differences into account when drafting the Pardon Clause. Id. Initially, the Pardon Clause mirrored the language of the English Act of Settlement, in stating that a pardon "shall not be pleadable in bar of an impeachment." Id. at 501. The language made sense in the English system, where impeachment proceedings could lead to both removal from office and criminal penalties. Id. at 503. The Act of Settlement language suggested that a pardon could not insulate an offender from removal by impeachment, but it could protect him from criminal penalties. Id. at 496.

In the American system, impeachment proceedings resulted only in removal from office. See id. at 503 ("In England, impeachment extend[ed] not only to removal from office but also to the more severe forms of punishment."). Thus, the Framers could say categorically that pardons were not available in impeachment cases. And that is the way the Pardon Clause ultimately read, affirming that pardons were permitted, "except for impeachment." See id. at 503 n.152 ("It was the more lenient extent of the impeachment power in America that motivated the insertion of the word 'except' for the phrase 'in bar of' . . . ."). The Supreme Court later observed that, while the Pardon Clause is based on the Act of Settlement, it "is an improvement upon the same." Ex parte Wells, 59 U.S. (18 How.) 307, 312 (1856).

${ }^{122}$ Duker, supra note 9, at 503. The Danby affair was an illustration of that power; in that case, Parliament voted both to remove Danby from office and to impose criminal penalties upon him. Id. at 487-96.

${ }^{123}$ U.S. CONST. art. I, § 3, cl. 7 ("Judgment in Cases of Impeachment shall not extend further than to removal from Office, and disqualification to hold and enjoy any Office of honor, Trust or Profit under the United States: but the Party convicted shall nevertheless be liable and subject to Indictment, Trial, Judgment and Punishment, according to Law."). Criminal penalties, thus, could not be imposed as part of the impeachment proceeding, though they could be imposed in a separate criminal prosecution. Id. 
That explicit language did not signify that the Framers meant to exclude common law rules. It simply meant that, in situations where the common law was uncertain, the Framers understood it would be prudent to include textual guidance. In other cases, where the relevance of common law rules was clear, the Framers expected those rules to be incorporated into the text of the pardon power without qualification. ${ }^{124}$

\section{B. The Objection from Historical Practice}

The second objection takes a different form, focusing on arguments from historical practice. Here the claim is that Presidents have repeatedly issued non-specific pardons throughout American history. That practice, the argument goes, justifies a new constitutional rule that overrides the original meaning of the Pardon Clause.

The argument from historical practice is not frivolous on its face. Case law supports the idea that historical practice is a relevant factor when interpreting the Constitution in certain kinds of cases-particularly in separation of powers cases. ${ }^{125}$ In these situations, a longstanding, unchallenged practice deserves deference, since it signifies the existence of a consensus view about the appropriate distribution of power. ${ }^{126}$ That doctrine certainly seems relevant here, given that the pardon power almost certainly implicates separation of powers concerns. ${ }^{127}$

${ }^{124}$ Duker, supra note 9 , at 529. This interpretation gains further credibility when one considers what the Framers would have needed to do to achieve the same results had the expressio unius rule of statutory interpretation applied. Namely, they would have had to specify the relevant common law rules in a comprehensive manner. The result would have been a long, unwieldy provision that would have run counter to their aspiration to draft a Constitution with a concise statement of governing principles. The choice they made - to rely on common law principles with clarifying textual rules - was eminently reasonable.

${ }^{125}$ This view can be traced back to the earliest Supreme Court cases: In McCulloch v. Maryland, Chief Justice Marshall wrote that, "a doubtful question, one on which human reason may pause and human judgment be suspended, in the decision of which the great principles of liberty are not concerned, but the respective powers of those who are equally the representatives of the people, are to be adjusted; if not put at rest by the practice of the government, ought to receive a considerable impression from that practice." 17 U.S. (4 Wheat.) 316, 401 (1819). Recent separation of powers cases have relied - to greater or lesser extent — on constitutional practice. See, e.g., Zivotofsky v. Kerry, 135 S. Ct. 2076, 2091 (2015) (quoting NLRB v. Noel Canning, 573 U.S. 513, 524 (2014)) (discussing separation of powers); Noel Canning, 573 U.S. at 514 (" $[\mathrm{I}] \mathrm{n}$ interpreting the Clause, we put significant weight upon historical practice. For one thing, the interpretive questions before us concern the allocation of power between two elected branches of Government.").

${ }^{126}$ Youngstown Sheet \& Tube Co. v. Sawyer, 343 U.S. 579, 610 (1952) (Frankfurter, J., concurring) ("The separation of powers built into our Constitution gives essential content to undefined provisions in the frame of our government. .. The Constitution is a framework for government. Therefore, the way the framework has consistently operated fairly establishes that it has operated according to its true nature. Deeply embedded traditional ways of conducting government cannot supplant the Constitution or legislation, but they give meaning to the words of a text or supply them.").

127 The pardon power, after all, gives the President the authority to suspend or override congressional rules, serving as a check on excessively punitive legislation. See Rachel E. Barkow, 
This is not to say that the historical practice argument is successful. As a preliminary matter, this kind of argument is not typically decisive. Where constitutional commands are clear-either because the text or original intent of the Framers is plain-historical practice does not control. As the Court has said, "[p]ast practice does not, by itself, create power." 128 Thus, historical practice "should guide our interpretation of an ambiguous provision" alone. ${ }^{129}$

That is one reason why historical practice arguments are so common in separation of powers cases. In many of those cases, the Court is called upon to assess the distribution of authority among the various branches without clear constitutional guidance. But this also highlights why historical practice arguments are less relevant in assessing the specificity requirement. Here, after all, the Framers' intent is clear: a specificity requirement exists, grounded in common law practices. As a result, historical practice cannot justify a new constitutional rule contrary to the Framers' intent. ${ }^{130}$

This conclusion suggests courts should give little or no weight to historical practice when considering the validity of the specificity requirement. Yet even if such evidence were deemed relevant, historical practice would offer no basis for rejecting the specificity requirement. This is so for two independent and fundamental reasons. First, a close look at the evidence reveals that, in fact, a deeply entrenched historical practice does

Clemency and Presidential Administration of Criminal Law, 90 N.Y.U. L. REV. 802, 829-33 (2015) ("The Framers and contemporary scholars have also seen the clemency power as a key part of the separation of powers because it allows the executive to check the legislative and judicial branches."). The separation of powers implications of the pardon power are touched upon in the Federalist Papers. Alexander Hamilton notes in Federalist 74 that: "The criminal code of every country partakes so much of necessary severity that without an easy access to exceptions in favor of unfortunate guilt, justice would wear a countenance too sanguinary and cruel." THE FEDERALIST NO. 74 (Alexander Hamilton). Even the most refined statutory code, in other words, requires a safety valve to account for exceptional cases.

Even more directly relevant, in at least one case the Supreme Court discussed historical practice when interpreting the scope of the pardon power. Thus, in Ex parte Grossman, the Court ruled that the President has the constitutional power to pardon criminal contempts. 267 U.S. 87, 122 (1925). Such a rule, the Court suggested, was supported, in part, by historical practice. Id. at 118 ("[C]riminal contempts of a federal court have been pardoned for eighty-five years. In that time the power has been exercised twenty-seven times.").

${ }^{128}$ Dames \& Moore v. Regan, 453 U.S. 654, 686 (1981); see also Noel Canning, 573 U.S. at 572 73 (Scalia, J., concurring) (standing for the same proposition). The Supreme Court has stated in a different context, the fact "that an unconstitutional action has been taken before surely does not render that same action any less unconstitutional at a later date." Powell v. McCormack, 395 U.S. 486, 546-47 (1969); see also Duker, supra note 9, at 524 (restating the holding from Powell).

${ }^{129}$ Noel Canning, 573 U.S. at 572-73 (Scalia, J., concurring).

${ }^{130}$ The Supreme Court's decision in Grossman is not to the contrary. Grossman, 267 U.S. at 112-13. In Grossman, the Supreme Court relied on historical practice to rule in support of the President's authority to pardon contempt. But in that case, the common law and other interpretive tools supported the conclusion that the President can pardon for contempt. Thus, historical practice was not utilized to override a clear constitutional rule; it was used as further support for a rule validated by other interpretive factors, including original intent. 
not exist in support of non-specific pardons. Second, even if such a practice did exist, it should be discounted because of certain unique features relevant to the pardon process.

\section{No Historical Practice Exists for Non-Specific Pardons}

Is there a historical practice in support of vague pardons? That one might believe the answer is "yes" might not be surprising. After all, the most famous pardon in recent memory was President Ford's pardon of Richard Nixon, which directly violated the specificity requirement. That pardon absolved Nixon of guilt "for all offenses against the United States which he ... has committed or may have committed or taken part in during the period from January 20, 1969 through September 8, 1974." 131

The memory of that pardon might persuade citizens to believe that vague pardons are a common occurrence. But such an inference would be a mistake, representing what cognitive theorists call the "availability bias." When certain events are more easily brought to mind, human beings tend to overestimate their prevalence. ${ }^{133}$ In fact, President Ford's vague pardon was an exceptional occurrence, not a common event.

A review of pardons during the last eight presidential administrations makes this clear. Between 1974 and 2018, a total of 2191 pardons were issued. ${ }^{134}$ Of these, President Ford's pardon of Nixon was only one of two pardon orders that potentially violated the specificity requirement. The other occurred on Christmas Eve of 1992, when President George H.W. Bush issued an executive order that pardoned members involved in the Iran-Contra affair. The group included four individuals who were pardoned after being convicted (Elliott Abrams, Alan Fiers, Clair George, and Robert C. McFarlane) and two others who were pardoned after indictment but before trial (Duane R. Clarridge and Caspar W. Weinberger).

That pardon was written in an unusual manner. It gave a full, complete, and unconditional pardon to the six defendants "for all offenses charged or prosecuted by independent counsel Lawrence E. Walsh or committed by these individuals and within the jurisdiction of that office."135 The non-italicized portion of this language is fully consistent with the specificity

\footnotetext{
${ }^{131}$ Proclamation No. 4311, supra note 7.

${ }^{132}$ Daniel Kahneman, Thinking Fast And Slow 424 (2011).

${ }^{133}$ For a concise discussion of this cognitive bias, see Molly J. Walker Wilson, The Expansion of Criminal Registries and the Illusion of Control, 73 LA. L. REV. 509, 552-56 (2013) and Amos Tversky \& Daniel Kahneman, Judgment Under Uncertainty: Heuristics and Biases, 185 SCIENCE 1124, 1127-28 (1974).

134 Clemency Statistics, DEP'T JUST., https://www.justice.gov/pardon/clemency-statistics (last updated July 11, 2019). These include pardons granted by Presidents Ford (382 pardons), Carter (534), Reagan (393), Bush (74), Clinton (396), G.W. Bush (189), Obama (212), and Trump (10, through Aug. 1, 2019).

${ }^{135}$ Proclamation No. 6518, 28 WeEKLY COMP. PrES. Doc. 2382 (Dec. 24, 1992) (emphasis added).
} 
requirement, since it limits the pardon to crimes outlined in the indictments and convictions. But the italicized portion is a different matter. This phrase encompasses any crime that the special prosecutor might charge within his jurisdiction in the future. In failing to define the kinds of crimes that might be pardoned, the language arguably violates the specificity requirement. ${ }^{136}$

With the Iran-Contra pardons added in, the total number of vague pardons would still remain vanishingly small. It would mean that, over forty-four years, seven out of 2191 pardons were problematic. ${ }^{137}$ That comes out to $.3 \%$ over the period.

This number ignores one other category of presidential orders that might seem relevant to the analysis - general amnesties. Like pardons, amnesties insulate an offender from criminal liability. They differ from ordinary pardons in that they are issued to groups of unnamed offenders, rather than to select, identified individuals. ${ }^{138}$ Although the word "amnesty" is not

${ }^{136}$ Whether it actually violates the specificity requirement is a matter of debate. First, the questionable language in the pardon is not actually operational, since the offenders had not yet been charged with additional crimes, and it is not clear that they could have been. Consequently, the additional language could be viewed as superfluous; a kind of presidential dicta.

Second, President Bush, in issuing the pardons, couched them in terms of rewarding individuals who carried out hazardous foreign policy and military missions. Indeed, Bush self-consciously situated the pardon within a list of military amnesties, comparing his order with "James Madison's pardon of Lafitte's pirates after the War of $1812, \ldots$ Andrew Johnson's pardon of soldiers who had fought for the Confederacy, ... [and] Harry Truman's and Jimmy Carter's pardons of those who violated the Selective Service laws in World War II and Vietnam." See Associate Press, The Pardons; Text of President Bush's Statement on the Pardon of Weinberger and Others, N.Y. TIMES (Dec. 25, 1992), https://www.nytimes.com/1992/12/25/us/pardons-text-president-bush-s-statement-pardon-weinbergerothers.html (statement by President Bush when announcing the pardon). As discussed in more detail later in this Section, these kinds of military pardons or amnesties may be exempt from the specificity requirement.

${ }^{137}$ Database of pardons on file with author. Besides the 2191 pardons discussed above, we also have relevant information about 2314 pardons from 1961 through 1974 (spanning the administrations of Presidents Kennedy, Johnson, and Nixon). According to one study, all but three of these pardons were issued after conviction. See Charles D. Berger, The Effect of Presidential Pardons on Disclosure of Information, 52 OKLA. L. REV. 163, $191 \mathrm{n} .160$ (1999) (citing A Pardon for Nixon and Watergate Is Back, CONG. Q. WKLY., Sept. 14, 1974, at 2458). For the post-conviction pardons, it is reasonable to assume that the President knew of the specific charges and either explicitly referred to the charges in the relevant indictments or at least implicitly limited the pardons to those charges. We do not know if the three pre-conviction pardons satisfied the specificity requirement. But even if all three were vaguely worded, the percentage of non-specific pardons during this period would be miniscule: . $1 \%$ over the entire period.

${ }^{138}$ See, e.g., Brown v. Walker, 161 U.S. 591, 601-02 (1896) (noting that an amnesty "is rarely, if ever, exercised in favor of single individuals, and is usually exerted in behalf of certain classes of persons, who are subject to trial, but have not yet been convicted"); Knote v. United States, 95 U.S. 149, 153 (1877) ("[T]he term [amnesty] is generally employed where pardon is extended to whole classes or communities, instead of individuals ...."); United States v. Hall, 53 F. 352, 355 (W.D. Pa. 1892) ("Pardons are granted to individual criminals by name; amnesty to classes of offenders or communities. They differ, not in kind, but solely in the number they severally affect."); see also Samuel T. Morison, Presidential Pardons and Immigration Law, 6 STAN. J. C.R. \& C.L. 253, 291 (2010) (“Analytically, an amnesty is not really a separate form of relief under the Pardon Clause, but merely signifies a pardon extended to an entire class of unnamed persons falling within the specific terms of the grant, typically enacted by a means of a presidential proclamation, rather than a clemency warrant issued to one or more 
mentioned in the Constitution, courts have ruled that amnesties are authorized under the Pardon Clause of the Constitution. ${ }^{139}$ In effect, amnesties are a special kind of pardon.

Since amnesties have the same legal roots as pardons, they would seem relevant to our discussion of pardon practices. But including amnesties in the analysis does not change the conclusion. Out of a total of approximately thirty amnesties, twenty specify the offenses covered by the order and thus are fully consistent with the specificity requirement. ${ }^{140}$ Two more implicitly limit the scope of the pardon to specific offenses. ${ }^{141}$ Finally, one pardon was enacted pursuant to a treaty, thus resting on independent constitutional grounds. ${ }^{142}$ That leaves only seven amnesties that lack references to specific offenses (i.e., conflict with the specificity requirement). If all seven were treated as vague pardons, the total number of vague pardons would still be a tiny amount - a total of fourteen pardons out of 2191 (or .6\%).

At the same time, the appropriateness of looking to amnesties as a point of reference is questionable. Although both amnesties and individual pardons are rooted in the same constitutional provision, they have important differences. ${ }^{143}$ The most fundamental difference, for our purposes, concerns the kinds of offenses for which amnesties typically apply. Amnesties are almost always issued for offenses relating to military conflict. ${ }^{144}$ Thus, they

identifiable grantees.”); Henry Weihofen, Legislative Pardons: Another View, 27 CALIF. L. REV. 387, 391 (1939) (“The difference between amnesty and pardon - 'general' or 'special pardon,' if one likeslies ... in the character of the act. The [pardon] remits punishment to a named person. The [amnesty] remits punishment for an offense, without particular reference to those who committed it.").

13920 Op. Att'y Gen. 330, 332 (1892) (Amnesties "only enable[] [the President] to do that in one act which he might do by a thousand. The power which the Executive exercises is still the pardoning power, and that the Constitution gives him."). The Supreme Court has gone so far as to say, in dicta, that the "distinction between amnesty and pardon is of no practical importance." Brown, 161 U.S. at 601; see also Knote, 95 U.S. at 153 ("[T] he distinction between [amnesty and pardon] is one rather of philological interest than of legal importance.").

${ }^{140}$ See infra Appendix A.

${ }^{141}$ See Proclamation (Dec. 8, 1863), in 6 A Compilation of the Messages And PaPers of the PRESIDENTS 1789-1897, at 213, 213-15 (James D. Richardson ed., 1897) (proclamation by President Lincoln asserting that amnesty is limited to the crime of treason, given the preamble's language referring to both treasons explicitly and to earlier statutes that identify treason as the focus of concern); Proclamation (May 29, 1865), in 6 A COMPILATION OF THE MESSAGES AND PAPERS OF THE PRESIDENTS 1789-1897, supra, at 310, 310-11 (proclamation by President Andrew Johnson indicating that amnesty refers to and mirrors Lincoln's earlier amnesty of December 8, 1863, and so similar limitations presumably apply). Cf. In re Stetler, 22 F. Cas. 1314, 1315 (Cir. Ct. E.D. Pa. 1852) (No. 13,380) (showing that the preamble of a pardon is relevant in assessing pardon's scope).

${ }^{142}$ Treaty with the Cherokees, Cherokees-U.S., art. II, Aug. 6, 1846, 9 Stat. 871.

${ }^{143}$ Burdick v. United States, 236 U.S. 79, 94-95 (1915) ("They are of different character and have different purposes."). For example, the Court has explained, an amnesty "overlooks the offense," while "remit[ting] punishment." Id. One possible implication is that acceptance of a pardon implies acceptance of guilt, while the application of an amnesty does not.

${ }^{144}$ Amnesty, in 2 ENCYCLOPEDIA OF THE SOCIAL SCIENCES 37 (1930) (“[A]mnesties of a general nature usually follow civil disturbances which have threatened the government . ..."); Morison, supra note 138, at 291 ("Presidents have utilized this mechanism of pardon relief repeatedly throughout 
are commonly used to reconcile combatants after fighting, ${ }^{145}$ absolve a deserter of guilt, ${ }^{146}$ or show gratitude to soldiers who have fought in battle. ${ }^{147}$

Amnesties of this sort directly or indirectly implicate the President's Article II commander-in-chief powers. These powers lie at the very heart of executive authority. ${ }^{148}$ For this reason, amnesties deserve a particularly deferential kind of review and, arguably, should be exempted from procedural rules pertaining to pardons, including the rule that a pardon satisfy the specificity requirement. ${ }^{149}$

Though this conclusion has never been tested in the Supreme Court, at least one circuit court has reached a similar conclusion, albeit perhaps for different reasons. In Greathouse, a federal circuit court observed that, "if a man be attained of felony, and get a pardon which doth not mention the attainder, the pardon will be ineffectual." 150 After expressing some skepticism about the continuing viability of such a rule, the court added that, regardless, the specificity requirement has no application to a proclamation of amnesty or general pardon to a number of offenders as a class. ${ }^{151}$

American history to restore social peace after periods of war and other episodes of political upheaval."); Weihofen, supra note 138, at 392 (The purpose of amnesties historically "was similar to that of a treaty which ends hostilities between different nations when both nations retain their independence. The acts of amnesty ended hostilities between warring factions, when neither faction was exterminated or expelled."). This distinct feature is consistent with the historic uses of the amnesty power, going back to classical times. See id. at 392 (Amnesties are "Act[s] of Grace" of a special sort, "its use in English history was precisely the same as in Greek and Roman history. It put an end to rebellion, civil war or disturbance, in which it was not desired to exterminate or expel all guilty persons.").

${ }^{145}$ E.g., Proclamation No. 483 (July 4, 1902), reprinted in A SUPPLEMENT TO A COMPILATION OF THE Messages AND PAPERS OF THE PRESIDENTS 1789-1902, at 392, 392-94 (George Raywood Devitt ed., 1903) (granting amnesty for insurrectionists in Philippines).

${ }^{146}$ E.g., Amnesty and Pardon, 43 Stat. 1940 (Mar. 5, 1924) (granting amnesty for certain World War I deserters).

${ }^{147}$ E.g., Proclamation No. 2676, 10 Fed. Reg. 15,409 (Dec. 24, 1945) (granting amnesty for certain persons active in the armed forces after July 1941).

${ }^{148}$ The Framers understood the heightened social interests at play in granting amnesties. In one of the only substantive discussions of the Pardon Clause in the Federalist Papers, Alexander Hamilton justified the President's broad pardon powers on the grounds that a well-placed amnesty might be essential for avoiding internal conflict after wartime. As Hamilton wrote: "[T]he principal argument for reposing the power of pardoning in . . . the chief magistrate is this: in seasons of insurrection and rebellion, there are often critical moments, when a well-timed offer of pardon to the insurgents or rebels may restore the tranquillity of the commonwealth." THE FEDERALIST No. 74 (Alexander Hamilton); see also Duker, supra note 9, at 504-05 (explaining the reasoning behind the executive pardon power).

${ }^{149}$ The Supreme Court has recognized that different procedural rules apply to amnesties compared to ordinary pardons. For example, the Supreme Court has suggested that courts should take judicial notice of amnesties but not pardons. See Jenkins v. Collard, 145 U.S. 546, 560-61 (1892) (Granting of amnesty to Civil War rebels is a "public proclamation of the President, which has the force of public law, and of which all courts and officers must take notice, whether especially called to their attention or not.").

${ }^{150}$ In re Greathouse, 10 F. Cas. 1057, 1059 (Cir. Ct. N.D. Cal. 1864).

${ }^{151} \mathrm{Id}$. at 1060 ("But this reason can have no application to general acts of amnesty and pardon, which are intended to include whole classes of offenders, and are in no respect founded on any consideration of the circumstances of particular cases, except of those which by name or special description may be excepted out of them."). 
The implication is that amnesties should not be considered as part of the historical practice relevant to our study, at least when they are issued for wartime infractions. The only "amnesties" that deserve our attention are those issued for offenses outside the military and national security context. ${ }^{152}$ How many general pardons of this sort exist? Of the roughly thirty amnesties issued over the nation's history, only one involves ordinary criminal activity.

That amnesty occurred in 1917, when President Wilson issued amnesty for all individuals currently serving a suspended sentence. Those suspended sentences had all recently been declared unconstitutional by the Supreme Court. ${ }^{153}$ In his amnesty proclamation, Wilson noted that returning these individuals to prison would lead to significant hardship and potential injustice, especially since many seemed to be living blameless lives. ${ }^{154}$ Particularly relevant for our purposes is the fact that the amnesty was written in extremely broad language. It applied to any federal offense that generated a suspended sentence. In that sense, it violated the specificity requirement.

This single example of an amnesty for ordinary criminal activity should be included in our list of non-specific pardons, rather than the seven non-specific amnesties mentioned previously. In that case, the total number of pardons and "amnesties" that involve non-specific offense language falls to eight out of 2191 , or $.4 \%$. Needless to say, this is hardly a "systematic, unbroken, executive practice, long pursued." ${ }^{155}$ Rather, it is best described as exceptionally rare.

152 The word "amnesties" is surrounded with quotation marks in the text because the term is used here solely to refer to offenses relating to military conflict. Under that definition, an executive order absolving run-of-the-mill crimes for a class of offenders might more accurately be described as a "general pardon," rather than an amnesty.

${ }^{153}$ See Proclamation of the President of the United States (June 14, 1917), in SuPPLEMENT TO THE Messages and Papers of the PResidents Covering the SECOND Term of WoOdrow Wilson, MARCH 4, 1917, TO MARCH 4, 1921, at 8318, 8318-19 (1921) (granting amnesty to persons who received a suspended sentence during a specified period). The amnesty was triggered by a Supreme Court decision, Ex parte United States, 242 U.S. 27 (1916). The case is sometimes referred to as the Killits decision after the judge who imposed one of the suspended sentences. As the Court in Killits explained, it has long been the practice of district courts to suspend a sentence indefinitely. Id. at 50-51. Indeed, at the time of the Killits decision, there were in excess of two thousand persons at large on suspended sentences, most if not all of whom were convicted of ordinary criminal offenses. Id. at 52. Killits declared that this practice was illegal, and that courts lacked lawful power to suspend criminal sentences. Id. at 51-52. The implication was that released offenders would be returned to prison.

${ }^{154}$ Wilson's proclamation mirrors the Supreme Court's own statements in Killits. As the Court noted, grave concerns had been raised that, as a result of its ruling, "misery and anguish and miscarriage of justice may come to many innocent persons" by its ruling. The Court responded by stating that a "complete remedy may be afforded by the exertion of the pardoning power." Killits, 242 U.S. at 52.

155 Youngstown Sheet \& Tube Co. v. Sawyer, 343 U.S. 579, 610 (1952) (Frankfurter, J., concurring). 


\section{Practical Obstacles to Challenging Pardons}

The flaws in the historical practice argument are even greater than these numbers suggest. Even if one were to conclude, counterfactually, that a large number of vague pardons were sprinkled throughout American history, that pattern would still not make the historical practice argument compelling. To understand this point, we need to clarify why a "systematic, unbroken, practice" might be relevant in constitutional interpretation.

The standard explanation is that such a pattern suggests a consensus among the political branches regarding the appropriate distribution of government power - a consensus that deserves respect when interpreting the Constitution's separation of powers requirements. ${ }^{156}$ In the pardon context, however, a practice cannot generate such an inference. The reason is that the political branches lack obvious opportunities or incentives to challenge the President's pardon practices. Consequently, the failure to challenge a vague pardon should not imply a consensus; it may simply reflect a lack of realistic opportunities to push back. ${ }^{157}$

Congress, for example, has limited options for challenging executive pardons. The Supreme Court has stated that pardons are entirely insulated from congressional control. ${ }^{158}$ Individual legislators are also powerless to challenge executive pardons in court, primarily because of strict standing rules. To bring suit, a legislator would need to "allege the deprivation of a legislative prerogative, such as nullification of a vote or deprivation of the opportunity to vote on legislative business." ${ }^{.159}$ A pardon does neither. ${ }^{160}$

\footnotetext{
${ }^{156}$ See Jane E. Stromseth, Understanding Constitutional War Powers Today: Why Methodology Matters, 106 YALE L.J. 845, 880-82 (1996) (reviewing LOUIS FISHER, PRESIDENTIAL WAR POWER (1995)) (The fact that Congresses have repeatedly "failed to object . . . even when [they] had an opportunity to do so," creates at least an inference that the body consented to the executive action. (alterations in original)).

${ }^{157}$ One might imagine other scenarios where the opportunity to challenge a practice does not exist. For example, if an executive action occurs in secret without other branches being aware of it (say, secret surveillance of citizens), the fact that such a practice has occurred is not grounds for saying that a consensus among the branches of government exists in support of it.

${ }^{158}$ Ex parte Garland, 71 U.S. (4 Wall.) 333, 380 (1867).

159 Matthew Hall, Who Has Standing to Sue the President over Allegedly Unconstitutional Emoluments?, 95 WASH. U. L. REV. 757, 768 (2017). In effect, standing exists when a plaintiff suffers an institutional injury that amounts to vote nullification. See Raines v. Byrd, 521 U.S. 811, 823, 826 (1997) (distinguishing between "vote nullification" and "abstract dilution of institutional legislative power").

${ }^{160}$ Such suits might have a better chance if Congress as a whole brought suit. Such actions are extremely rare. See Alissa M. Dolan, CONG. ReSEARCh SeRV., R43712, ARTiCle III STANDING AND CONGRESSIONAL SUITS AGAINST THE EXECUTIVE BRANCH 1 (2014) (standing found only four times in forty-one years, with three of the four times concerning enforcement of congressional subpoenas).

Some courts have suggested that standing is more likely when legislatures lack any other remedy to challenge executive practices. Id. at 7-8. This was suggested in Campbell v. Clinton, which involved a claim that President Clinton's use of force was a violation of the War Powers Act and his constitutional authority. 203 F.3d 19, 19 (D.C. Cir. 2000). The D.C. Circuit noted that plaintiffs "enjoy[ed] ample legislative power to have stopped prosecution of the "war" "including the ability to pass a law forbidding
} 
Congress, of course, might initiate impeachment proceedings to express its opposition to the President's failure to observe the specificity requirement. But that is an extreme remedy, and it seems unrealistic to expect Congress to take that action each time the President issues a non-specific pardon, especially in the run-of-the-mill criminal case. Indeed, given the lack of awareness about the common law limits on the pardon power, it would be extraordinary if Congress started the complex machinery of impeachment on the grounds that a pardon violated a procedural rule. ${ }^{161}$ Congress, in short, has few realistic options to challenge a vague, non-specific pardon. ${ }^{162}$

If Congress is poorly positioned to police the boundaries of the specificity requirement, one might think that it counts for something that the third branch of government - the federal judiciary — has made virtually no mention of the specificity requirement in the past 230 years. But this is really not surprising. Challenges to pardons are extremely rare, for obvious reasons. The only entities that seem likely to have standing to challenge a pardon are the two parties to the case - the defendant and the prosecutor. ${ }^{163}$

the use of U.S. forces or restrict funding for American participation in the conflict through the appropriations power. $I d$. at 23 . The court also stated that "there always remains the possibility of impeachment should a President act in disregard of Congress' authority on these matters." Id. What counts as a legislative remedy remains unclear in the pardon context. See DOLAN, supra, at 13-14 (noting that existing case law has not specifically defined what constitutes a legislative remedy). As a result, this consideration may cut both ways. On one hand, the legislature always has impeachment as remedy for challenging improper pardons. On the other hand, short of that extreme remedy, Congress has limited options.

${ }^{161}$ Even if Congress were to initiate impeachment proceedings in more high-profile cases (such as George H.W. Bush's pardon of the Iran-Contra conspirators), it would not be clear that this action signified Congress' view that the pardon was unconstitutional; rather it might simply reflect a belief that the pardon was based on illicit motives, an entirely different rationale.

162 Another option might be for Congress to adopt non-binding resolutions declaring a vaguely-drafted pardon unlawful. Again, in the case of a run-of-the mill pardon, it is highly unlikely for Congress or its committees to take such a step, and it is not clear that such a resolution would be counted as part of the relevant historical practice.

One of the few formal efforts to repudiate a presidential pardon occurred soon after the Civil War, when Andrew Johnson granted amnesty to Confederates fighting the Union armies. Following that action, the Senate Judiciary Committee issued a report declaring the amnesty invalid (on the grounds that the amnesty lacked congressional authorization). S. REP. NO. 40-239, at 2-3 (1869). I am not aware of any congressional action, however, criticizing pardons on specificity grounds. Given the infrequency of such pardons, however, that silence may not be entirely surprising.

${ }^{163}$ Ordinary members of the public lack standing to bring such a challenge, since they do not have the kind of concrete injury required to bring suit. See, e.g., Lujan v. Defs. of Wildlife, 504 U.S. 555, 57374 (1992) ("We have consistently held that a plaintiff raising only a generally available grievance about government-claiming only harm to his and every citizen's interest in proper application of the Constitution and laws, and seeking relief that no more directly and tangibly benefits him than it does the public at large - does not state an Article III case or controversy."); McCord v. Ford, 398 F. Supp. 750, 755 (D.D.C. 1975) ("When a President exercises [the] authority to pardon, as he frequently does, his action ... cannot be reviewed by a court on the mere complaint of a citizen." (quoting Koffler v. Ford, Civil No. 74-1406 (D.D.C. Sept. 25, 1974))). 
However, except in the most unusual case, the defendant - the recipient of a pardon-would be loath to challenge a pardon. ${ }^{164}$ That leaves the prosecutor as the principal entity in a position to dispute a pardon's validity. Yet prosecutors are not the most promising agents for vindicating the specificity requirement's relevance.

As a preliminary matter, a prosecutor may have limited standing to bring a challenge, particularly in cases where the pardon is issued after sentencing. Whether standing exists in such cases would depend on whether the prosecutor is seen as having a continuing interest in the case after its completion. Since most pardons occur after sentencing, this may prove a significant limitation on the prosecution's ability to challenge a pardon. ${ }^{165}$

Even assuming a prosecutor could challenge the validity of a pardon, she would face significant institutional obstacles in doing so. Prosecutors are part of the executive branch and formally under the direction of the Attorney General and, through her, the President. ${ }^{166}$ A President, concerned about a disobedient U.S. Attorney, could remove the prosecutor from office. As a

A court could, on its own initiative, review the validity of a pardon, but it is unlikely to do so absent a motion from the parties themselves or special circumstances. Conn. Bd. of Pardons v. Dumschat, 452 U.S. 458, 464 (1981) ("Unlike probation, pardon and commutation decisions have not traditionally been the business of courts; as such, they are rarely, if ever, appropriate subjects for judicial review."). In exceptional cases, it is conceivable that a court might, on its own, hold a hearing to review the validity of a pardon short-circuiting the criminal process supervised by the judge. One example is President Trump's pardon of Sheriff Arpaio. See Richard M. THOMPSON II, CONG. RESEARCH SERV., LSB10186, CAN THE PRESIDENT PARdon CONTEMPT OF COURT? PROBABLY YeS. 1-2 (2018) (discussing procedure leading to review of Arpaio pardon). What made that case unusual is that the pardon implicated the court's own enforcement powers, which may explain the court's belief in its authority to review the pardon. It remains unclear whether courts have authority to hold such hearings in other pardon cases where no one challenges the pardon.

${ }^{164}$ One of those exceptionally rare circumstances arose in Burdick. For details, see supra note 20. Burdick appears to be the only Supreme Court case where a defendant challenged the pardon on the grounds that it lacked appropriate specificity about the offense. Burdick v. United States, 236 U.S. 79, 93 (1915). There, the Supreme Court sidestepped that issue, ruling in Burdick's favor on other grounds. Id. at 91,93 .

${ }^{165}$ There is also the awkward question whether a prosecutor, who is ostensibly representing the executive branch, has standing to challenge conduct by the President of the United States, the head of the executive branch. Can the executive branch sue itself? Some precedent from the Watergate era suggests the answer is yes, under appropriate circumstances. See United States v. Nixon, 418 U.S. 683, 691-92 (1974) (highlighting the potential legal issues for suing a President for contempt); see also Akhil Reed Amar, Nixon's Shadow, 83 MinN. L. REV. 1405, 1405-08 (1999) (discussing Leon Jaworski's standing to sue Richard Nixon).

${ }^{166}$ The President retains the ultimate power to fire the Attorney General, as well as individual U.S. Attorneys. 28 U.S.C. $§ 541$ (a) (2012). Despite this power, individual prosecutors retain a degree of independence regarding how they pursue investigations. See Bruce A. Green \& Rebecca Roiphe, Can the President Control the Department of Justice?, 70 ALA. L. REV. 1, 35 (2018) ("United States Attorneys and other subordinate DOJ lawyers are, in theory, subject to the Attorney General's specific direction, although, as a practical matter, subordinate prosecutors maintain substantial autonomy . ..." (footnote omitted)). Moreover, the legal authority of the President to control the course of specific investigations, short of firing prosecutors, remains controversial. See id. at 30-31 (discussing Supreme Court decisions that have questioned limiting the President's ability to discharge independent prosecutors). 
practical matter, then, it would be highly unusual for an ordinary prosecutor to challenge a pardon issued by the chief executive of the nation.

The most likely scenario where a challenge would occur would be in cases involving a special prosecutor of some sort, one who is appointed to investigate executive branch malfeasance and who, through regulation or law, maintains some degree of independent prosecutorial authority. ${ }^{167}$ Few cases over the nation's history meet those requirements, if only because independent or special prosecutors are of relatively recent vintage. ${ }^{168}$

The two examples that come closest to satisfying these requirements are the pardons of Richard Nixon and the Iran-Contra conspirators. ${ }^{169}$ In both cases, the pardons were issued in the face of special prosecutor investigations. Additionally, questions arose about whether they were issued

${ }^{167}$ Various types of independent prosecutors have been utilized in the past, including "special prosecutors," "special counsels," and "independent counsels." For a useful glossary of terms, see Cynthia Brown \& Jared Cole, Cong. Research Serv., R44857, Special Counsel InVESTIGATIONS: History, AUTHORITY, APPOINTMENT AND REMOVAL 2 (2019). In this Article, I use the term "independent prosecutor" to refer to a federal prosecutor appointed to investigate the executive branch and who, for political and/or legal reasons, possesses a significant degree of independence from ordinary Department of Justice oversight. In practice, this encompasses special prosecutors and special counsel appointed under either the Ethics in Government Act (when in force) or Department of Justice regulations.

${ }^{168}$ Until the Watergate era, the use of independent prosecutors was rare. See KATY J. HARRIGER, The Special Prosecutor in American Politics 41-42 (2d ed. 2000) (explaining that Watergate placed special prosecutors "on the agenda" of Congress). In 1973, pursuant to Department of Justice guidelines, Attorney General Elliot Richardson appointed special prosecutor Archibald Cox to investigate allegations of executive abuse. The President subsequently ordered Cox fired, triggering the so-called Saturday Night Massacre. BROWN \& COLE, supra note 167, at 3.

Though legal, the President's actions carried a heavy political cost and hastened his downfall. To insulate special prosecutors from presidential control, Congress subsequently enacted the 1978 Ethics in Government Act. The Act authorized a three-judge panel to appoint a "special prosecutor" (subsequently called an "independent counsel") to investigate criminal wrongdoings. The Act proved controversial, and it was left to expire in 1999. In its stead, the Department of Justice enacted regulations to authorize the Attorney General to appoint lawyers from outside the government to serve as a "special counsel" in cases where potential conflicts of interest might exist. Special prosecutors are considered to be somewhat independent from the rest of the executive branch. Among other things, they are "not subject to 'day-today supervision' by any official and are vested 'within the scope of his or her jurisdiction, the full power and independent authority to exercise all investigative and prosecutorial functions of any United States Attorney." BROWN \& COLE, supra note 167, at 1.

Robert Mueller was appointed subject to these regulations. Office of Deputy Attorney Gen., Order No. 3915-2017, Appointment of Special Counsel to Investigate Russian Interference with the 2016 Presidential Election and Related Matters (May 17, 2017), https://www.justice.gov/opa/pressrelease/file/967231/download. While ultimately removable by the President, Mueller enjoyed a degree of independence, and he remained in the job despite the President's stated desire to see him removed.

${ }^{169}$ In Richard Nixon's case, a special prosecutor had been appointed to investigate possible presidential misdeeds. The investigation into Nixon's crimes was cut short when Ford issued a pardon to the former President. Macgill, supra note 5, at 61. The pardons in the Iran-Contra case also cut short the trials of at least two of the six co-conspirators, while freeing the other four from the consequences of their convictions. See Carl Levin, The Iran-Contra Pardons: Was It Wrong for Ex-President Bush to Pardon Six Defendants?, 79 A.B.A. J. 44, 44 (1993) (explaining the consequences of the pardon and arguing that the Iran-Contra pardons undermine independent counsels). 
for self-serving, improper motives. ${ }^{170}$ Of the two, the Nixon pardon was the most vulnerable to challenge, since it was crafted in exceptionally broad language. ${ }^{171}$ Some on Leon Jaworski's staff reportedly supported contesting the pardon. ${ }^{172}$ For unclear reasons, Jaworski chose not to take such a dramatic step. ${ }^{173}$

The point of this extended discussion is straightforward: Even if, counterfactually, one were to find a historical practice in support of non-specific pardons, one cannot assume this implies an interbranch consensus on their validity. One can infer such an agreement only when

170 The Iran-Contra pardons were viewed as problematic by some commentators, who saw the pardons as efforts by President Bush to stymie investigations that might prove embarrassing for the Bush Administration. See, e.g., Christopher E. Smith \& Scott P. Johnson, Presidential Pardons and Accountability in the Executive Branch, 35 WAYNE L. REV. 1113, 1115 (1989) ("[T]he Iran-Contra episode raises the possibility that a pardon could be motivated by the personal self-interest of the President who could halt criminal proceedings in order to suppress information about his own misdeeds.").

The Nixon pardon was even more controversial, with some going so far as to claim that Ford reached a deal with Nixon to pardon him in exchange for the presidency. See, e.g., Laura Kalman, Gerald Ford, the Nixon Pardon, and the Rise of the Right, 58 CLEV. ST. L. REV. 349, 361 (2010) (discussing "suspicions [Ford] had made a deal with Haig," though ultimately concluding that "[t]hose suspicions were apparently groundless"); Did Gerald Ford Agree to Nixon Pardon Before Taking Office?, DEMOCRACY NOW! (Dec. 27, 2006), https://www.democracynow.org/2006/12/27/did_gerald_ford_ agree to nixon (last visited Oct. 10, 2019) (indicating that Victor Navasky, Publisher Emeritus of The Nation, stated that Ford's statement regarding Nixon's pardon was "an attempt to put a gloss of innocence on a deal they had made"). Others believed that Ford sincerely felt a pardon was in the public interest. Some of this latter group nonetheless felt he acted prematurely. Richard Ben-Veniste, the former Chief of the Watergate Taskforce of the Special Prosecutor's office, took this position. As he explained:

Had Ford kept to his original plan and allowed time for formal charges to be lodged against Nixon, spelling out the specifics of his culpability, it would have been up to Nixon to either accept the pardon or fight the charges in court. But pardoning Nixon without requiring at least an acknowledgment of responsibility for serious misconduct and for lying to the public left the door open for the spate of revisionist books and articles that followed the resignation.

Richard Ben-Veniste, The Pardon in History's Hindsight, WASH. POST (Dec. 29, 2006), http://www.washingtonpost.com/wp-dyn/content/article/2006/12/28/AR2006122801054.html; see also Charles D. Berger, The Effect of Presidential Pardons on Disclosure of Information: Is Our Cynicism Justified?, 52 OKLA. L. REV. 163, 166-68 (1999) (discussing the impact of pardon on public information concerning Watergate and related scandals).

${ }^{171}$ See Proclamation No. 4311, supra note 7 (demonstrating the broad language of the Nixon pardon). The Special Prosecutor could have challenged the pardon by indicting the President, requiring him to plead the pardon in return. That would have provided an opportunity to litigate the pardon's validity.

${ }^{172}$ Warren Weaver, Jr., Experts Assert Some Nixon Legal Problems Remain, N.Y. TimES (Sept. 10, 1974), https://www.nytimes.com/1974/09/10/archives/experts-assert-some-nixon-legal-problemsremain-court-review.html.

${ }^{173}$ The special counsel in the Iran-Contra case, Lawrence Walsh, had a more difficult route to challenging the Bush pardon. To do so, he would have had to file new charges that were not listed in the specific pardon language. If the defendants then tried to use the pardon to avoid prosecution, Walsh would have had an opportunity to challenge the pardon order. Of course, this tactic rested on the assumption that Walsh could have identified additional charges relevant in the case. 
other branches have an opportunity to challenge and dispute the practice. Indeed, without such an opportunity, unconstitutional practices would become law simply by being insulated from attack. Presidential pardons benefit from that kind of insulation as they are largely immune from legislative control or judicial review. ${ }^{174}$ Thus, even if we assume for the sake of argument that a history of vague pardons exists, that practice would deserve little or no interpretive weight.

\section{DONALD TRUMP AND THE SPECIFICITY REQUIREMENT}

The specificity requirement is a modest limitation on presidential power. It requires the President to specify the particular offense that he or she intends to pardon, either by identifying the crime or by referring to charges listed in an indictment or conviction. The rule does not prevent the President from granting mercy to any person or for any crime, and it does not require a significant change in practice. Presidents have typically satisfied the requirement when issuing pardons. If that is the case, one may wonder if the formal adoption of the specificity requirement would be particularly significant. The answer is that it may in fact prove vitally important, in light of the increased risk today that pardons will be used for self-interested, partisan, and corrupt reasons.

Since the 1970s, several controversial pardons have come to the public's attention. Two of the most obvious are President Ford's pardon of Nixon and President Bush's pardon of the Iran-Contra defendants. Commentators have argued, with more or less persuasiveness, that both of these pardons were made for illicit motives. ${ }^{175}$ More recently, President Clinton's pardon of Marc Rich was widely seen as a payoff to a major campaign contributor. ${ }^{176}$

President Trump brings the danger to a new level. In his first year of office, the President has issued highly questionable pardons to supporters, such as Dinesh D'Souza and Joe Arpaio. Even more egregiously, he has threatened to use the pardon power to disrupt investigations into his own, potentially criminal, conduct. Thus, the President seems to have hinted at the possibility of offering a pardon to his former campaign chairman, Paul

${ }^{174}$ See Maddie McMahon \& Jack Goldsmith, The Executive Branch's Extraordinarily Broad View of the Presidential Pardon Power, LAWFARE (May 31, 2018, 10:17 AM), https://www.lawfareblog.com/ executive-branchs-extraordinarily-broad-view-presidential-pardon-power (noting that since 1866 the Supreme Court has held that pardon power is not subject to legislative control and that there is only a possibility that pardons may be reviewed by courts).

${ }^{175}$ See supra text accompanying notes 169-70 (discussing Ford's pardon of Nixon and Bush's pardon of the Iran-Contra defendants).

${ }^{176}$ See, e.g., Editorial, An Indefensible Pardon, N.Y. TIMES, Jan. 24, 2001, at A 18; E.J. Dionne, Jr., Bill Clinton's Last Outrage; The President's Defenders Feel Betrayed by His Pardon of Marc Rich, BROOKINGS (Feb. 6, 2001), https://www.brookings.edu/opinions/bill-clintons-last-outrage-thepresidents-defenders-feel-betrayed-by-his-pardon-of-marc-rich/. 
Manafort. The purpose of such an offer is not certain, but it appeared to be motivated by a desire to undercut the Special Counsel's leverage over Manafort. ${ }^{177}$

If the President carries through on these threats, he may be tempted to issue a broad, non-specific pardon. A vague pardon of this sort-such as a pardon for "all felonies" committed over a period of time - would leave the nature of the immunized conduct uncertain. ${ }^{178}$ In that way, it would create a fog of ambiguity that could help the President avoid scrutiny and controversy. ${ }^{179}$

Given the elevated risk of a self-interested pardon, the specificity requirement gains heightened significance. The requirement offers a number of benefits, some of which have been touched on in earlier sections. At a most basic level, the specificity requirement guards against a pardon that unintentionally applies to crimes beyond the President's intent or knowledge. For example, on a charitable reading, President Trump might honestly believe that Paul Manafort (or Roger Stone or Michael Flynn) has been unfairly targeted by the special prosecutor. Even so, if Trump issues a

${ }^{177}$ See, e.g., Natasha Bach, Trump's Latest Tweets Hint at Pardon for Paul Manafort-But Nothing for Michael Cohen, FORTUNE (Aug. 22, 2018), https://fortune.com/2018/08/22/trump-tweets-manafortcohen/; Telegraph Reporters, Donald Trump Says He's Considering Pardon for Paul Manafort, TELEGRAPH (Aug. 23, 2018, 3:06 PM), https://www.telegraph.co.uk/news/2018/08/23/donald-trumpsays-considering-pardon-paul-manafort/ (discussing President Trump's potential pardon of Paul Manafort).

${ }^{178}$ This is particularly true when a non-specific pardon is made preemptively (i.e., before indictment). In that case, knowledge of the offender's wrongdoings may be particularly obscure, generating a particularly heavy fog around what precisely is being vacated. Richard Nixon's pardon was criticized for precisely this reason, with some arguing that President Ford should have waited until after indictment to pardon Nixon. That way, the public would have at least been clear about which crimes Richard Nixon had committed.

Given the ambiguous scope of a preemptive pardon, the Office of Legal Counsel has warned that such pardons should only be used in the most exceptional cases. Pardoning Power of the President, 6 Op. Att'y Gen. 20-21 (1853) ("[I]t has been held unwise and inexpedient, as a general rule, to interpose the pardoning power in anticipation of trial and condemnation, although particular circumstances may exist to justify such an exceptional act on the part of the President."). Tellingly, the Attorney General's Office has also stated that, when preemptive pardons are issued, details of the recipients' crimes and guilt should be articulated. Id. ("The President of the United States has, undoubtedly, the power to grant a pardon as well before conviction as afterwards. ... But there must be satisfactory evidence of some kind as to the guilt of the party."). Current Department of Justice regulations go even farther, stating that:

No petition for a pardon should be filed until . . a at least five years after the date of the release of the petitioner from confinement or, in case no prison sentence was imposed, until the expiration of a period of at least five years after the date of the conviction of the petitioner.

Eligibility for Filing Petition for Pardon, 28 C.F.R. § 1.2 (1999).

${ }_{179}$ Duker, supra note 9 , at 504 . As William Duker has observed, those arguing for an unfettered pardon power fail "to recognize the disadvantages connected with secrecy and the pardoning power: 'If the history of civilization proves nothing else, it proves that where secrecy cloaks the use of power it also cloaks the abuse of power."' Id. 
pardon for "all crimes" committed over a period of time, he may end up absolving the recipient of crimes of which Trump was not aware.

The more serious concern, of course, is that Trump is well aware of the crimes committed by his associates and wants to issue a pardon to protect himself from investigation. In that circumstance, a specificity requirement would serve an essential function. By requiring the President to be transparent about the specific offenses being pardoned, the requirement would deter the President from granting pardons for particularly egregious and problematic crimes. It is one thing to pardon an associate for all crimes committed in the past year, quite another to pardon the associate for, say, conspiring with a foreign power to disrupt the presidential elections.

Transparency in pardoning, in other words, raises the political costs of pardons. To be sure, a desperate President, fearing that investigators are hot on his heels, might still decide to grant a pardon to his underlings or associates. ${ }^{180}$ But forcing the President to list the crimes pardoned still serves a purpose: it publicly exposes the nature of the recipient's wrongdoing and thus permits public debate about the appropriateness of the pardon. In that way, the specificity requirement facilitates a debate about whether the pardon power has been misused and whether impeachment is an appropriate remedy.

Transparency is only the first of several important benefits generated by the specificity requirement. The rule also limits the scope of any individual pardon. With a specificity rule in place, a single pardon cannot give the recipient any guarantee that he won't be subject to a subsequent federal prosecution on different grounds. Thus, for example, Paul Manafort might hope that President Trump would pardon him for his crimes of conviction (and perhaps for other potential charges too). But he cannot be sure that the federal prosecutors would not bring up additional charges at some later time.

Someone like Manafort might hope, if new charges are brought, that President Trump would issue a second pardon encompassing the new indictments. But the need to issue repeated pardons raises the political cost to the President, requiring him to name and highlight new crimes each time. Even more importantly, a defendant could not be assured that Trump would still be in office when the new charges were brought, leaving him vulnerable to prosecution without a protector. In short, a specificity requirement would make pardons - and particularly preemptive pardons - less final and less valuable, undermining the prospective value of a pardon and increasing the pressure on the accused to cooperate with investigators. ${ }^{181}$

${ }^{180} I d$. at 504 ("Experience . . . has shown that a President could partake in a subversion of the Constitution and risk 'the damnation of his fame to all future ages."”).

${ }^{181}$ The specificity requirement would also make "preemptive pardons"- that is, pardons prior to indictment—-much less attractive. Because they are issued before conviction and indictment, preemptive pardons are issued without certainty over the ultimate charges that will be brought against the defendants. 
Finally, a specificity requirement would make the option of a "self-pardon" far less attractive to the President. Scholars, of course, are far from certain that a President has the constitutional authority to pardon himself, and they have good reasons to be skeptical. ${ }^{182}$ Nonetheless, even if a self-pardon were permissible, the specificity requirement would reduce its usefulness. To ensure he would be fully insulated from prosecution, a President would have to offer a comprehensive list of each and every possible federal crime he had committed. Should he miss a charge, the President would remain vulnerable to federal prosecution upon leaving office.

In the end, a specificity requirement cannot stop a desperate President from misusing the pardon power to hinder a federal investigation. But it can make the effort more difficult, and it can help bring to light the details of the crimes being absolved. Given the extraordinary breadth of the pardon power, and its anomalous role in the American constitutional system, the specificity requirement might seem like an exceptionally modest protection. Yet, the restriction may prove more significant than it first appears, resting as it does on a powerful insight, famously articulated by Justice Brandeis, that transparency may be the best remedy for governmental abuse. ${ }^{183}$

\section{CONCLUSION}

The argument for a specificity requirement is strong. It is justified under an originalist reading of the Constitution, and it is fully consistent with the core ideals of the nation's founding. Of course, to say that the Supreme Court

If lawful, vague and general preemptive pardons would be a particularly useful tool for a President seeking to cover up crimes, since that kind of pardon could be used to disrupt an investigation relatively early in the process and could be issued without naming particular charges. The specificity requirement thus reduces the appeal of preemptive pardons. To use a preemptive pardon in that situation, a President would need to speculate on the kinds of crimes that the recipient might be charged with, and the recipient would be left with the risk that the pardon would prove insufficient.

182 See Brian C. Kalt, Note, Pardon Me?: The Constitutional Case Against Presidential Self-Pardons, 106 YALE L.J. 779, 809 (1996) ("Presidents cannot pardon themselves."); James Pfiffner, Pardon Power, Heritage Found. Heritage Guide to Const., https://www.heritage.org/constitution/\#!/articles/2/essays/89/pardon-power (last visited Oct. 11, 2019) ("The possibility of a President pardoning himself for a crime is not precluded by the explicit language of the Constitution. . . . But a broader reading of the Constitution and the general principles of the traditions of United States law might lead to the conclusion that a self-pardon is constitutionally impermissible. It would seem to violate the principles that a man should not be a judge in his own case; that the rule of law is supreme and the United States is a nation of laws, not men; and that the President is not above the law."); see also Presidential or Legislative Pardon of the President, 1 Op. O.L.C. 370, 370 (1974) ("This raises the question whether the President can pardon himself. Under the fundamental rule that no one may be a judge in his own case, it would seem that the question should be answered in the negative.").

${ }^{183}$ Louis D. BRANDeis, Other People's Money AND How the Bankers USE IT 92 (1914) ("Publicity is justly commended as a remedy for social and industrial diseases. Sunlight is said to be the best of disinfectants; electric light the most efficient policeman."). 
should interpret the Pardon Clause to include a specificity requirement is not to say that it will do so. The Supreme Court often acts in mysterious ways, and it may turn a blind eye to the original meaning of the clause. ${ }^{184}$

Nonetheless, in the current political climate, even the possibility that the federal courts might adopt a specificity requirement is significant. Any individual who relies on the prospect of receiving a broad, unlimited pardon to insulate himself from prosecution must discount the value of that pardon by the risk that such a pardon might be vulnerable to challenge. ${ }^{185}$ As the prospective value of a vague pardon declines, the attractiveness of reaching a deal with the prosecution increases.

That leads to the final, and perhaps counterintuitive, point. Regardless of how the courts ultimately rule on this issue, simply starting a conversation about the validity of the specificity requirement might have a practical impact on the course of the various investigations into the 2016 election. Increased awareness about the vulnerability of general pardons to legal challenge strengthens the hand of the investigators. That, in turn, increases the likelihood that the truth about the campaign will emerge, whatever that truth is.

${ }^{184}$ Moreover, to bring a test case, a prosecutor like Robert Mueller would need to be willing to challenge an overly broad pardon.

${ }^{185}$ The defendant might receive a more specific pardon, of course, and avoid the danger. But such a pardon would be far less beneficial, since it would leave the defendant open to future prosecution should new facts emerge about possible wrongdoings. 
APPENDIX A: LIST OF AMNESTIES ${ }^{186}$

\begin{tabular}{|c|c|c|c|}
\hline Date & President & Recipients & $\begin{array}{l}\text { Offense } \\
\text { identified? }\end{array}$ \\
\hline $7 / 10 / 1795$ & Washington & $\begin{array}{l}\text { Pennsylvania Insurgents } \\
\text { during Fries Rebellion }\end{array}$ & Yes \\
\hline $5 / 21 / 1800$ & Adams & $\begin{array}{l}\text { Individuals prosecuted under } \\
\text { Alien \& Seditions Act }\end{array}$ & Yes \\
\hline $3 / 5 / 1804$ & Jefferson & Military deserters & Yes \\
\hline $10 / 15 / 1807$ & Jefferson & Military deserters & Yes \\
\hline $\begin{array}{l}\text { 2/7/1812; } \\
\text { 10/8/18/12; } \\
6 / 17 / 1814\end{array}$ & Madison & Barataria pirates for desertion & Yes \\
\hline $2 / 6 / 1815$ & Madison & $\begin{array}{l}\text { Certain persons who inhabited } \\
\text { New Orleans, adjacent area, } \\
\text { or Barataria Island. }\end{array}$ & $\mathrm{X}$ \\
\hline $6 / 12 / 1830$ & Jackson & $\begin{array}{l}\text { Cherokee Indians } \\
\text { (incorporated into treaty) }\end{array}$ & $\mathrm{X}$ \\
\hline $8 / 6 / 1846$ & Polk & $\begin{array}{l}\text { Political prisoners prosecuted } \\
\text { under Sedition Act }\end{array}$ & Yes \\
\hline $3 / 10 / 1863$ & Lincoln & Deserters & Yes \\
\hline $12 / 8 / 1863$ & Lincoln & $\begin{array}{l}\text { Persons who participated in } \\
\text { rebellion }\end{array}$ & Yes* \\
\hline $3 / 11 / 1865$ & Lincoln & Deserters & Yes \\
\hline $5 / 29 / 1865$ & Johnson & $\begin{array}{l}\text { Persons who participated in } \\
\text { rebellion }\end{array}$ & Yes* \\
\hline $9 / 7 / 1867$ & Johnson & $\begin{array}{l}\text { Persons who have committed } \\
\text { treason }\end{array}$ & Yes \\
\hline $7 / 4 / 1868$ & Johnson & $\begin{array}{l}\text { Persons who have committed } \\
\text { treason }\end{array}$ & Yes \\
\hline $12 / 25 / 1868$ & Johnson & $\begin{array}{l}\text { Persons who have committed } \\
\text { treason }\end{array}$ & Yes \\
\hline $12 / 13 / 1873$ & Grant & $\begin{array}{l}\text { Sailors and marines for } \\
\text { desertion }\end{array}$ & Yes \\
\hline $1 / 4 / 1893$ & Harrison & $\begin{array}{l}\text { Members of the Church of } \\
\text { Jesus Christ of Latter-day } \\
\text { Saints for bigamy }\end{array}$ & Yes \\
\hline 9/25/1894 & Cleveland & $\begin{array}{l}\text { Members of the Church of } \\
\text { Jesus Christ of Latter-day } \\
\text { Saints }\end{array}$ & Yes \\
\hline $6 / 21 / 1900$ & McKinley & Insurrectionists in the & $\mathrm{X}$ \\
\hline
\end{tabular}

186 The contents of this appendix were compiled by the author and his research assistants through the use of publicly available sources. The information and sources are on file with the author. 


\begin{tabular}{|l|l|l|l|}
\hline & & Philippine Islands & \\
\hline $7 / 4 / 1902$ & $\begin{array}{l}\text { T. } \\
\text { Roosevelt }\end{array}$ & $\begin{array}{l}\text { Insurrectionists in the } \\
\text { Philippine Islands }\end{array}$ & $\mathrm{X}$ \\
\hline $6 / 14 / 1917$ & Wilson & $\begin{array}{l}\text { Certain individuals under } \\
\text { suspended sentence }\end{array}$ & $\mathrm{X}$ \\
\hline $3 / 5 / 1924$ & Coolidge & Military deserters in WWI & Yes \\
\hline $12 / 23 / 1933$ & $\begin{array}{l}\text { F. } \\
\text { Roosevelt }\end{array}$ & $\begin{array}{l}\text { Individuals convicted of } \\
\text { violating espionage or draft } \\
\text { laws during WWI }\end{array}$ & Yes \\
\hline $12 / 24 / 1945$ & Truman & $\begin{array}{l}\text { WWII veterans who violated } \\
\text { federal law prior to military } \\
\text { service }\end{array}$ & $\mathrm{X}$ \\
\hline $12 / 23 / 1947$ & Truman & $\begin{array}{l}\text { Persons who violated draft } \\
\text { laws during WWII }\end{array}$ & Yes \\
\hline $12 / 24 / 1952$ & Truman & $\begin{array}{l}\text { Certain Korean War veterans } \\
\text { who violated federal law prior } \\
\text { to military service }\end{array}$ & $\mathrm{X}$ \\
\hline $12 / 24 / 1952$ & Truman & $\begin{array}{l}\text { Servicemen convicted of } \\
\text { desertion between the end of } \\
\text { WWII and start of Korean } \\
\text { War }\end{array}$ & Yes \\
\hline $9 / 16 / 1974$ & Ford & $\begin{array}{l}\text { Vietnam era draft evaders and } \\
\text { deserters }\end{array}$ & Yes \\
\hline $1 / 21 / 1977$ & Carter & Draft law violators & Yes \\
\hline
\end{tabular}

*An asterisk signifies that the offense was implied by language, but not explicit. 